\title{
ظاهرة الإعراب في الوقف و الإبتداء \\ "دراسة تحليلة نحوية"
}

\section{Sriwahyuningsih R Saleh, Berti Arsyad \\ Sastra Arab, Fakultas Ilmu Budaya - UMG}

$$
\text { تجريد البحث }
$$

هذا البحث يتكلم عن "ظاهرة الإعراب في الوقف و الابتداء "دراسة تحليلية نحوية". و هذا البحث الإثل

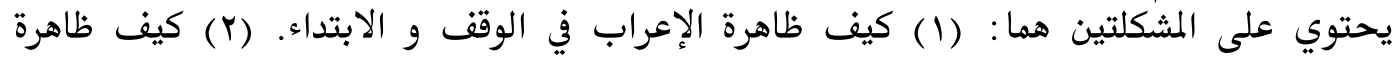

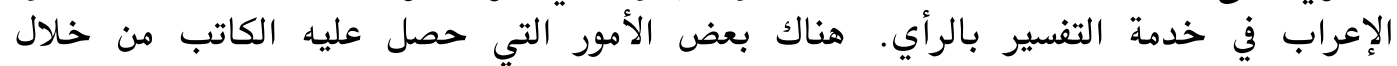

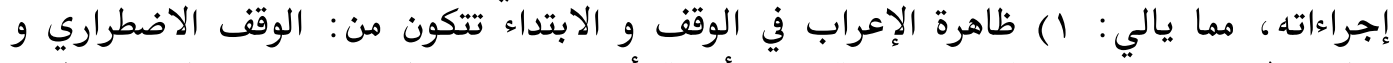

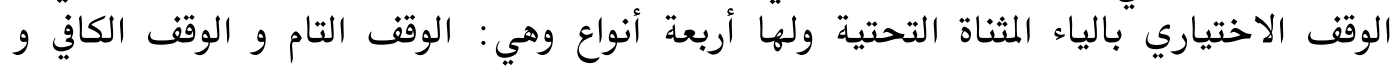

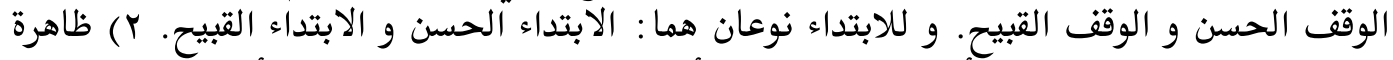

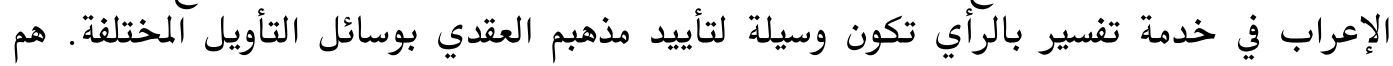
كالمعتزلة و المتصفون و الشيعة.

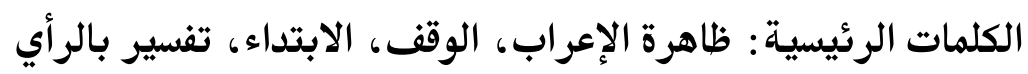
أ. أ. ألمقدمة

إن القرآن الكريم هو النص العربي المعجز، أعجز العرب، و هم أهل الفصاحة و البيان، و

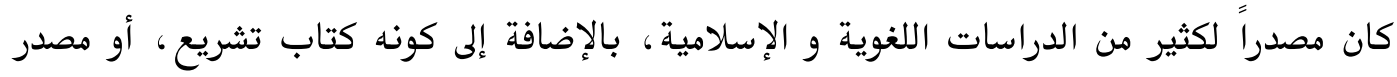
التشريع الأول، لذلك فقد كان هو المختار لدراسة التطبيقي الإعرابي فيه.

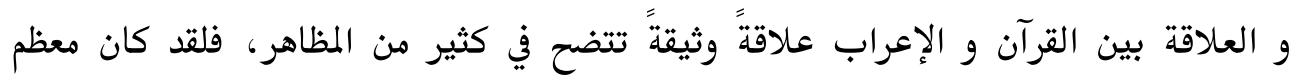
القراء من النحاة، و كان كل منهم يقعد لقراءته، و كان نقد القرآن-على يد أبي الأسواد- إعراباً، و ليس ببعيد عنا الكتب التي ألفت خالصة في إعراب القرآن، بل إن اللحن في قراءة القرآنإعراباً هو الذي دعا إلى نشأة النحو. و آيات القرآن يستشهد بها في كل أبواب النحو و عند كل الذحاة تقريباً. و كل كتب التفاسير تتعرض للإعراب في الكلمات و الجمل، حيث إنه مرتبط بالمعنى. هذا إلى أن العلوم الإنسانية بعامة يتصل بعضها من بعض. و الإعراب من أهم سمات اللغة العربية الفصحى، إن لم يكن أهم سماتها، حتى إن القداما

\section{'A Jamiy, Jurnal Bahasa dan Sastra Arab Volume 07, No. 2, September 2018}


سمو الذحو إعراباً، و الإعراب نحواً. و إن منا من يسمع إلى الخطيب فلا يلتفت إلى إتطلاق لسانه

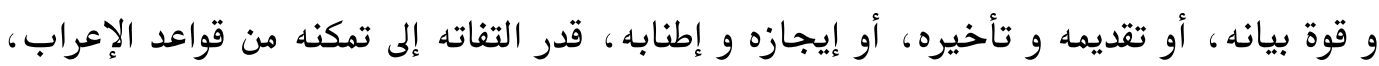

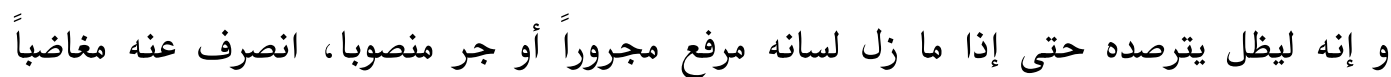
حائقاً و قد سقطت من عينه.

فإن الاهتمام بعلوم الكتاب والسنة، وتعلمهما والجد في تحصيلهما والإنصاف فيهم ا سبب خير كثير، والأمور بعواقبها منوطة ولن يخيب اللّه تعالى من صدَّق وصدَق.

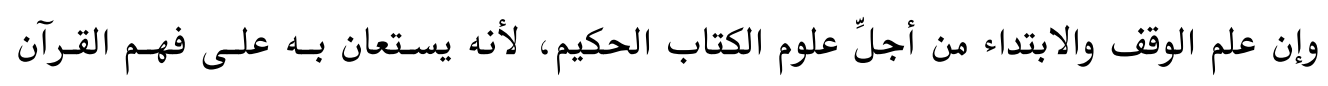
والغوص على درره وكنوزه وتتضح به الوقوف التامة، والكافية والحسـان، فتظهـر للسـامع المتأمسل

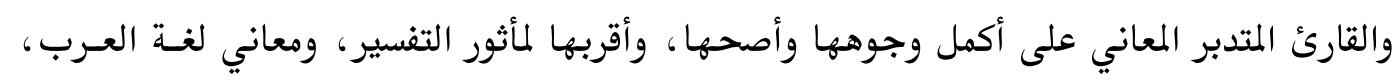
فإن اعتماد علماء الوقف والابتداء في وضع الوقوف وتفصيلها، وبيان وجوهها، مبني على النظر في

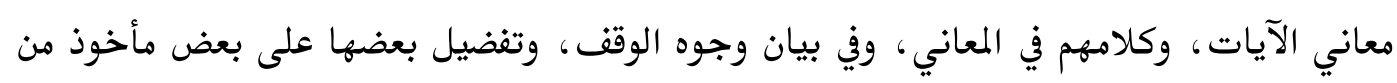
المنقول والمعقول. فلا ريب أن علم الوقف والابتداء من العلوم التي تفسر بها وجوه المعاني القرآنية؛ إذ المقصود منه بيان مواضع الوقف بحيث يراعي القارئ المعاني فيقف ويبتدئ على حسب ما يقتضيه المعنى واللفظ، ولا يكون ذلك إلا بتدبر واهتمام بالمعاني فالنظر في الوقف معين على التدبر. وإذا قرأ القارئ وابتدأ بما لا يحسن الابتداء به، ، أو وقف عند كلام لا يفهم إلا بأن يوصل بما

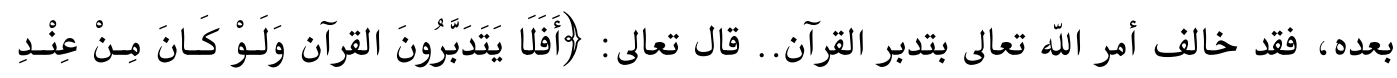

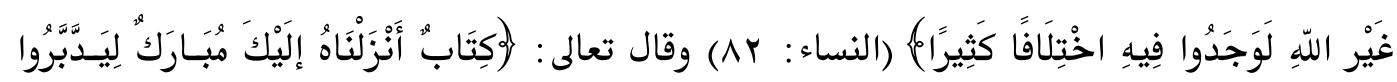

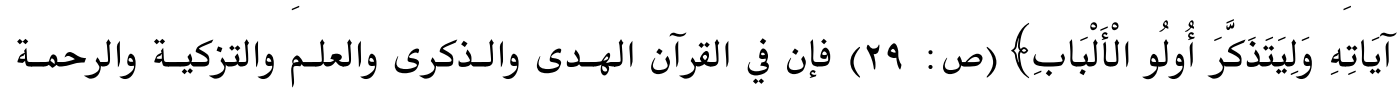

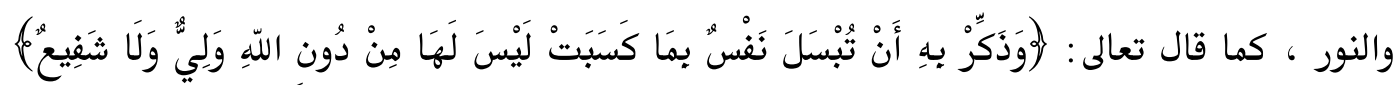

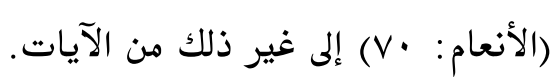
فهذا العلم من أجل علوم الكتاب المبارك ومع ما قدمت جلالته واعتناء قـراء السـلف بـه فقـــ كاد أن يصبح اليوم مهجورًا. ثم إن مسألة الوقف على رؤوس الآي من المسائل التي رأيت أنها تحتاج إلى بحث وتـرجيح، وبخاصة وقد اشتهر فيها القول الذي هو خلاف الراجح، إذ الراجح فيها التفصيل لا الإطلاق كمـا سيتبين إن شاء اللّه تعالى.

\section{'A Jamiy, Jurnal Bahasa dan Sastra Arab Volume 07, No. 2, September 2018}


فأردت أن أبين الراجح فيها بدليله وتعليله وأنقل ما لمحققي العلماء من الكلام فيها. فإن النظر في دلائل المسائل العلمية والبحث عن مذاهب الأئمة والعلماء فيها حق على أهل العلم وطالبي التحقيق وإن قنع بمجرد التقليد من قنع.

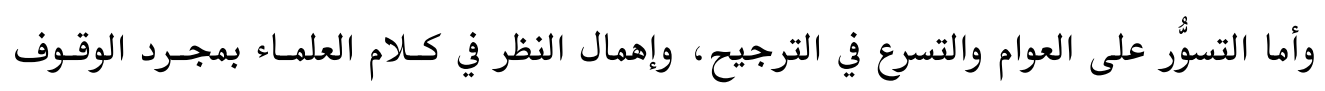

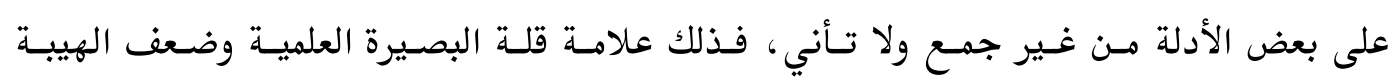
الإيمانية.

وإذا ما بحثت المسائل العلمية على وفق القواعد المعتبرة وتبين للباحث القول الراجح فلا شـك أن ذكره لوجه رجحانه ولو ببسط الأدلة أمر مغيد.

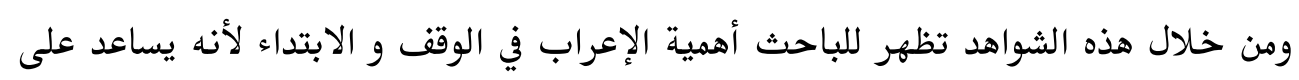
إزالة الغموض واللبس الذي يمكن أن يحدثا في اللغة لولا الإعراب وهو بالإضافة إلى ذلك يعد مظهرًا من مظاهر الدقة والجمال تتميز بهما اللغة العربية . فبعلم الوقف والابتداء يتحقق فهم كلام الله -تعالى- حيث لا يدرك معناه إلا بذلك، فمن لم يهتم به، فقد يقف قبل تمام المعنى، ولا يصل ما وقف عليه بما بعده، حتى ينتهي إلى ما يصح

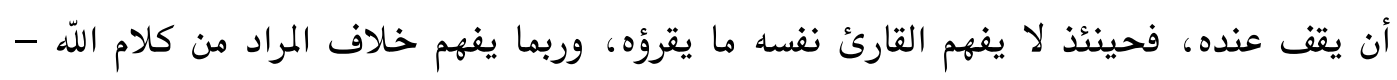
جل وعلا- إذا وقف على غير مواطن الوقف، إذ إن المعنى يتغير تبعًا لموطن الوقف في الكلام. فإن هدف تحليل على هذه الرسالة، هي شرح عن الدراسات التحليلية الذحوية في الوقف لهفي و الابتداء و خدمة تفسير بالرأي في القرآن الكريم. و هذا البحث الجديد يمكن أن يكون مغيدة للقارء لاستكشاف كيفية مظاهر الإعراب في الوقف و الابتداء من القرآن الكريم و ما يطبق فيها من

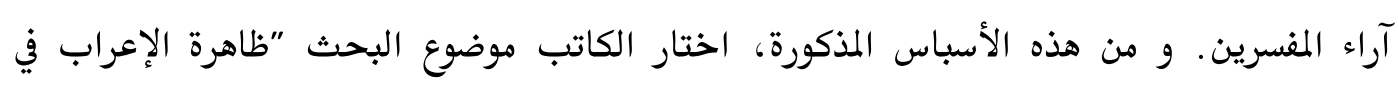
الوقف و الابتداء (دراسة تحليلة نحوية) ".

إذا أردنا أن نحجث عن بلاغة القران. أتينا إلي البحث عنها من هذه الوجود وضعنا ها

بين يديك . فننطر في الفاظه من جهة فصاحة وفي نظمه من جهة أخذ كل كلمة الموضع اللائق بها • وفي دلالته من جهة تصوير المعاني. وإيصالها إلى الأذهان من غير تعسف والتواء ثم في جملة ن جهة ما تحمل من المعاني التي يستدعي المقام مراعاتها .

\section{'A Jamiy, Jurnal Bahasa dan Sastra Arab Volume 07, No. 2, September 2018}


وفي هذا البحث يتركز في كلمة "ضرب " في القران الكريم حيث لقد ورد كثيرا من الأية

القرأنية ليست قليلة بل كثيرة ـ وقد تغير المعاني إلي عدة كثيرة ـ لما قارن بحرف جر أو زيادة حرف و مقارنة بصياغ أو كلمة أخري كيف يكون ذلك ـ هذا من عجائب العربية ـ لأن العريبة ليست فقط الأحرف هحائ متركبة ـ بل هي أو اللغة ـ وهي اللغة الثروة أخد مثالا واحدا ـ كلمة ضرب . أما من حيث اللغة هي بطش . وهي للمتعدي . ضرب القلب تحرك ـ ضرب في الماء . تحرك وسبح فيه . ضرب بين الناس أفسد بينهم وهذا كثير . وتجد أيها القاري عجبا في العربية. فإن هدف تحليل على هذه الرسالة، هي شرح عن الدراسات التحليلية النحوية في مضمونات معاني كلمة "ضرب" في القرآن الكريم. و هذا البحث الجديد يمكن أن يكون مفيد للقارء لاستكشاف معاني كلمة "ضرب" من القرآن الكريم. و من هذه الأسباس المذكورة، اختار الكاتب موضوع البحث " معاني كلمة "ضرب" في القرآن الكريم (دراسة تحليلة نحوية)".

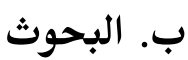
ا أ) تعريف الذحو

تعريف النحو لغة، النحو : الطريق و الجهة و هو مشتق من الفعل نحا و الجمع أنحاء و نُحُوٌ، و نحوت الشىئُ قصدته فالنحو : القصد، و منه نحو العربية، و هو إعراب الكلام العربي، لأن المتكلم ينحو به منهاج كلام العرب إفرادا و تركيباً، و النحوي العالم بالنحو، و الجمع نحويون و نحاة.

قال ابن جني أن النحو هو انتحاء سمت كلام العرب، في تصريفه من إعراب و غيره، كالتثنية و الجمع، و التحقير و التكسير و الإضافة، و النسب، و التركيب، و غير ذلك، ليلحق من ليس من أهل اللغة العربية بأهلها في الفصاحة، فينطق بها و إن لم يكن منهم، و إن شد بعضهم عنها رد به إليها ا ـ و الحقيقة أن ابن جني قد سبق علماء عصره بهذا النص و جاء بما تعارف عليه اللغويون المحدثون، فقد جمع في هذا النص بين لونين من الدراسات: صرفية و تنضح في التثنية و الجمع و التحقير (التصغير)...، و نحوية: تنضح في الإضافة و

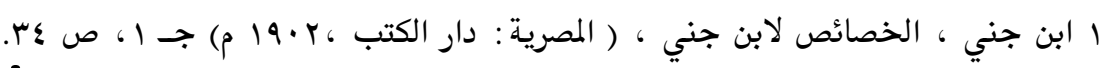


الإعراب و التركيب. و هذان النوعان من الدراسة و هما الصرف (Morphology) و التركيب

(Gynaxe) و لتفصيل ذلك أقول : إن الدراسات اللغوية الحديثة تجمع بين علم النظم و علم التراكيب(Synaxe) ، و علم الصيغ الصرفي(Morphology) تحت باب واحد و هو باب النحو (Grammar) (بر)

ا. فأما علم النظم أو التراكيب (Synaxe) فهو يعني أول كل شيئ بترتيب الكلمات في جمل أي أنه يدرس الطرق التي تتألف بها الجمل من الكلمات. و يهتم هذا العلم أيضاً بأشياء أخرى لا تقل أهمية عن تركيب الكلمات و تأليفها في الجمل، من هذه الأشياء البحث في قوانين المطابقة (Concord) أو عدم المطابقة من حيث العدد (الإفراد و التثنية و الجمع) من حيث النوع (التأنيث و التذكير) مثلاً. و من وظيفة علم التراكيب كذلك البحث في الإعراب و قوائنه. r. الشق الثاني من علم النحو و هو علم الصيغ (Morphology) و هو ما يعرف في الأوســــــاط اللغوية بعامة بعلم الصرف، و يقوم بدراسات الوحدات الصرفية و الصيغ اللغوية التي يتركب منها الكلام أو الجمل. فهذا الشق الثاني (الوحدات الصرفية و الصيغ اللغوية) أساس الشق الأول - علم التراكيب- و مكوناته. و تؤكد الدراسات اللغوية الحديثة أن علم التراكيب هو أشبه ما يكون ببناء كبير، مادته الوحدات الصرفية أو تسمى الموريفيماتس.

و من هذين الفرعين معاً تنتج الفصائل النحوية ( Grammatical Catagories) كفصيلة العدد: المفرد و المثنى و الجمع، و فصيلة الجنس : المذكر و المؤنث، و فصيلة التعريف و التنكير: النكرة و أنواع المعارف و هي الضمير و العلم و أسماء الإشارة و الموصولة و المعرفة بال، و فصيلة الزمن : كماضي الفعل المضارعه و ظرف الزمان، و فصيلة الاشتقاق : كاسم الفاعل و المفعول و اسم الزمان و المكان و اسم الآلة و أفعل التفضيل و اسم المرة و اسم الهيئة و الصفة المشبهة و الصيغة المبالغة، و فصيلة التوابع كالصة و العطف و البدل و التوكيد، و فصيلة النعاني الوظفية: كالفاعلية و المفعولية و الاضافة و الاستثناء و التمييز.

\section{'A Jamiy, Jurnal Bahasa dan Sastra Arab Volume 07, No. 2, September 2018}




$$
\text { ب) واضع الذحو }
$$

وردت رواياتٌٍ شتَّى عن واضع الذحو، تتحدَّث عنه من جوانبه المختلفة، تتحدَّث عن

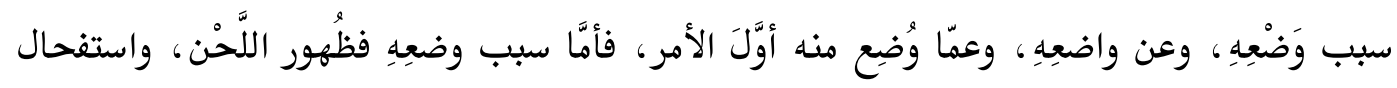

$$
\text { خَطَرِهِ على مَرِ الأيام. }
$$

وكانت العرب تَمْقُت اللَّحْنَ أشدَّ المَتْتِ ، وتراه مَنْقَصَةً تُزرِي بصاحِبها، لا فِ مطلع الإسلام

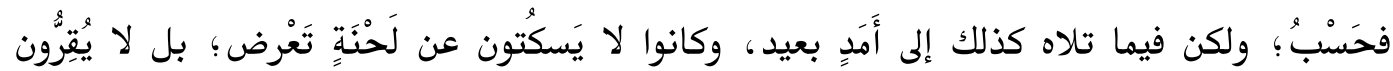

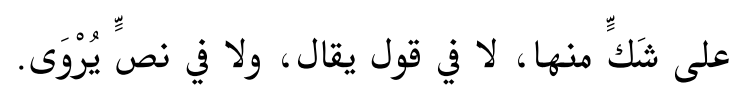

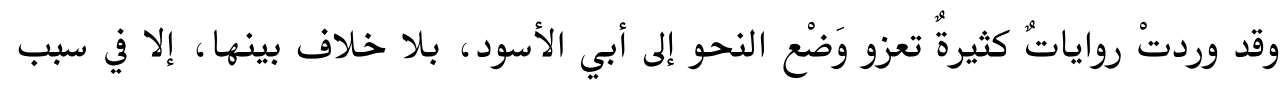

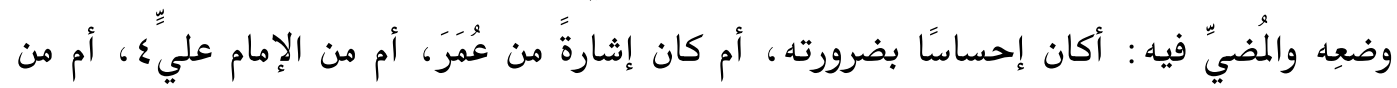

زياد؟

ويبدو أنَّ الأمر شُبِّهَ على القائلين بإشارة عمر، وإثارة زياد، فحَسِبَ الأولون أنَّ عَهْدَ عمر

إلى أبي الأسود في تعليم الإعراب - يعني إشارةً بوضع النحو، وحَسِبَ الآخرون أنَّ نَقْطَ أبي إني

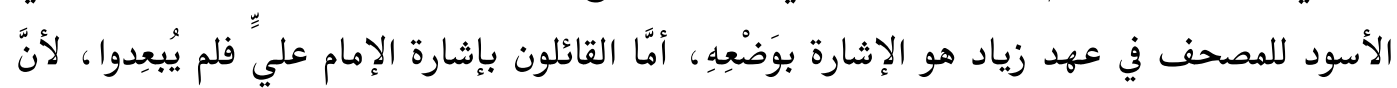

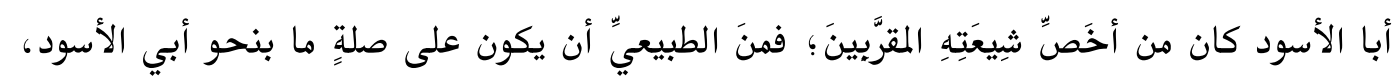
إشارةً به أو إرشادًا فيه.

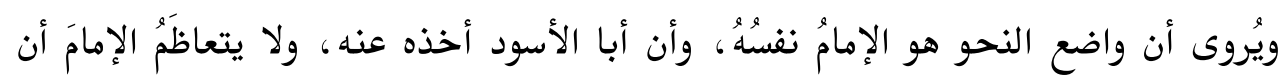

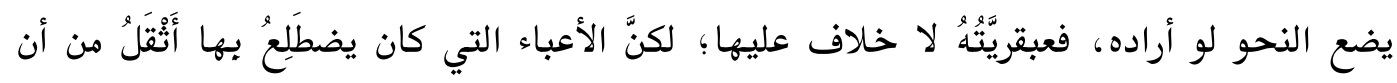

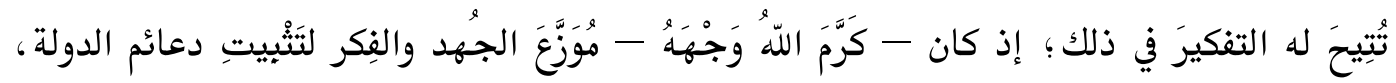

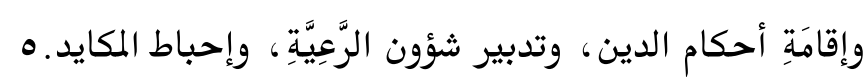

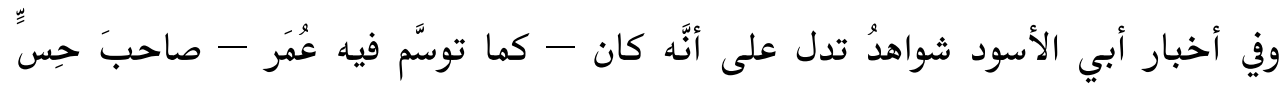

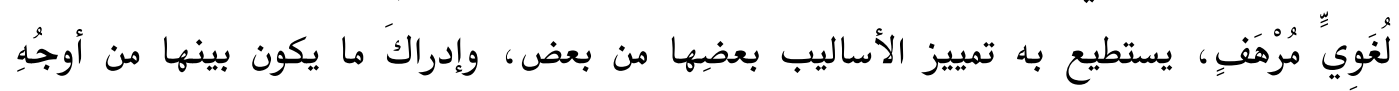
الخلاف والمشابهة ، وما يكون لذلك من أثر في المعنى صحة وفسادًا.

؛ Www.alukah.net/literature

。

\section{'A Jamiy, Jurnal Bahasa dan Sastra Arab}

Volume 07, No. 2, September 2018 


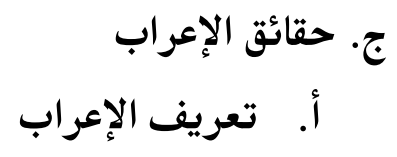

جاء في اللسانج عدة معان لكلمة الإعراب، منها :

ا. فالإعراب بمعنى الإيضاح أو الإفصاح و منه قول - صلى الله عليه و سلم- (الثيب

تعرب عن نفسها- أي تفصح) و يقال : أعرب عما في ضميرك أي أبن.

r. أعرب الرجل: تزوج امرأة عروباً أو عربة و هي المرأة الضاحكة المتحببة إلى زوجها العاشقة له، المظهرة له ذلك، و بذلك فسّر قوله تعالى (عرباً أتراباً (سورة الواقعة آية لrV) السامع بإعرابه كما تتودد المرأة العروب إلى زوجها ل . و عندي أن المعنى الثاني يتصل

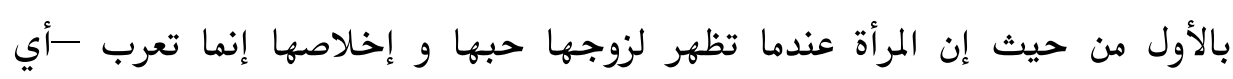
توضح و تفصح- عن ذلك.

r. و من هذا المادة عند ابن جني^ (عروبة) و العروبة (نكرة و معرفة) و ليوم الجمعة، و و

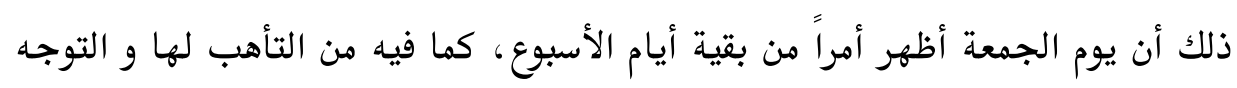

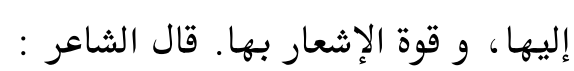

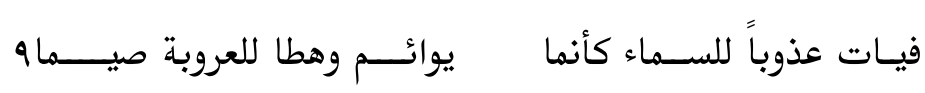
ع. ثم يتطور المعنى الثانى و هو إظهار التودد و العشق من المرأة لزوجها إلى الفحش من

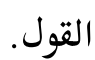

ه. . التعريب اتخاذ فرس عربي، كما أن التعريب في اللغة اتخاذ المنهج العربي (و منه عربة الفرس تعربا إذا بزغته ، و ذلك أن تذسف أسفل حافره، و معناه أنه قد بان بذلك ما

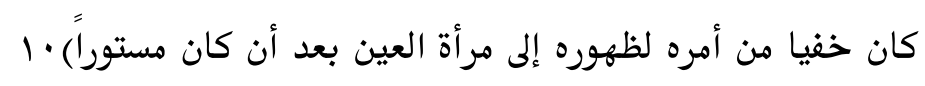

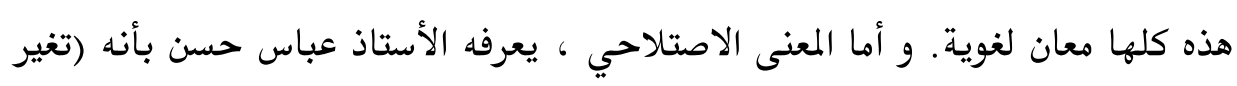

\section{'A Jamiy, Jurnal Bahasa dan Sastra Arab} Volume 07, No. 2, September 2018

דابن منظور، لسان العرب، طا, ص 111

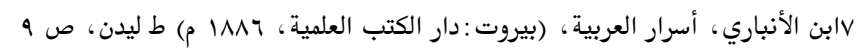

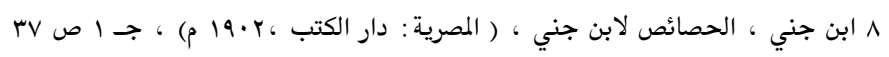

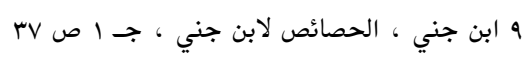

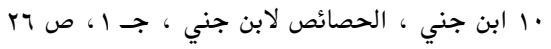


العلامة التي في آخر اللغظ، بسبب تغير العوامل الداخلية عليه، و ما يقتضيه كل عامل) 11 و في الشذور (الإعراب أثر ظاهر أو مقدر يجعله العامل في آخر الاسم الـمتمكن و الفعل

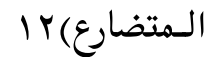

و في حاشية الصيان على الأشموني (الإعراب في الاصطلاح مذهبان: الأول لفظي و اختاره النظم-يقصد ابن مالك-و نسبه إلى الـهحققين و عرفه في التسهيل بقوله : ما جيء به لبيان مقتضى العامل من حركة أو حرف أو سكون أو حذف. و مذهب الثاني معنوي

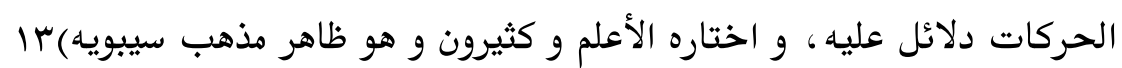

$$
\text { د. ظاهرة الإعراب في الوقف و الإبتداء }
$$

$$
\text { ( ) ظاهرة الإعراب في الوقف }
$$

يرتبط كل من الوقف و الابتداء و الإعراب بالآخر ارتباطاً وثيقاً، إذ أن الوقف و الابتداء

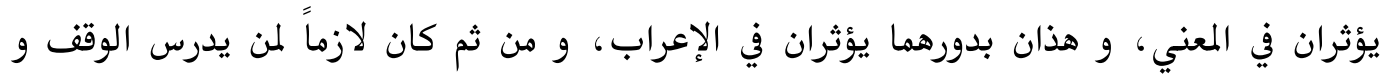

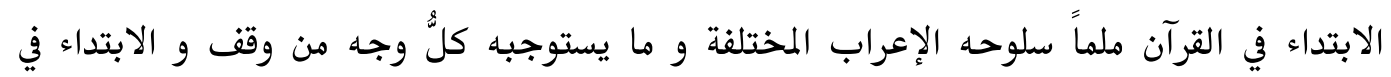
القراءة عند الموضوع معين. إلى مس المشتغلين بعلوم القرآن من اتخذ الإعراب و الفصائل النحوية مقياساً لبيان مواضع الوقف و الابتداء. الوقف و الابتداء عنصران من العناصر الصوتية في اللغة و قد عرفهما ابن الجزري بأنه الوقف قطع الصوت عن الكلمة زمناً يتنفس فيه عادة بنية استئناف القراءة، إما بما يلي الحرف الموقوف عليه، أو بما قبلهـاء ، و أما الابتداء هو الشروع في قراءة كتاب الله سواء كان بعد قطع وانصراف عنها أو بعد وقف. و مما يدل على اتمام المسلمين الأوائل بعلم الوقف في القرآن أنهم كانوا يساوون بين تعلم الوقف و تعلم القرآن نفسه، يدل على ذلك ما رواه عبد الله بن عمر من (أنهم كانوا يعلمون ما ينبفي أن يوقف عنده كما يتعلمون القرآن) ذلك أن المعنى متوقف على الموضع الذي يقف عنده القارئٔ، و ربما يقف القارئ على موضع يخل بالمعنى و يؤدي إلى التعسف في الإعراب، و في ذلك يقول ابن الجزري (ليس ما يتعسفه بعض المعربين، أو تكلفه بعض القراء، أو يتأوله بعض أهل الأهواء مما يقتض وقفاً أو ابتداء - ينبغي أن يعتمد الوقف عليه- بل ينبغي تحري المعنى الأتم و

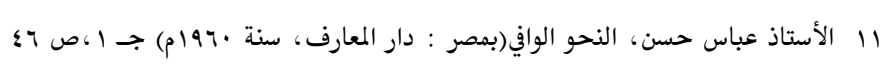

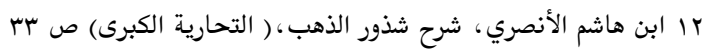

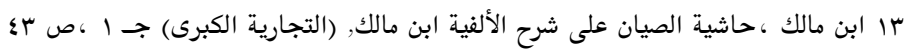

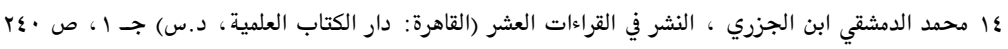

\section{'A Jamiy, Jurnal Bahasa dan Sastra Arab


الوقف الأوجه) الثم يأتي ابن الجزري بأمثلة من التعسف و التحمل في الوقف الذي يؤدي إلى إلى التعسف في الإعراب أيضاً، فمن ذلك:

\begin{tabular}{|c|c|c|c|c|}
\hline سورة & الوقف & & الآية & رقم \\
\hline البقرة: YN & "أنت" & 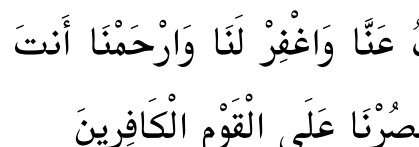 & مَوْلَانَا فَاعَنْ & 1 \\
\hline \multicolumn{3}{|c|}{ منادى بحروف (أنت) تأكيداً لضمير الفاعل في (ارحمنا)، و تكون (مولانا) } & & \\
\hline
\end{tabular}

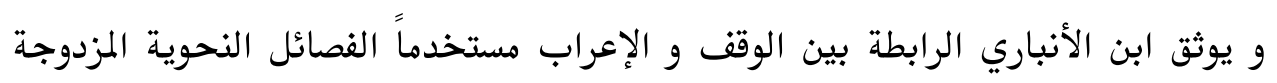

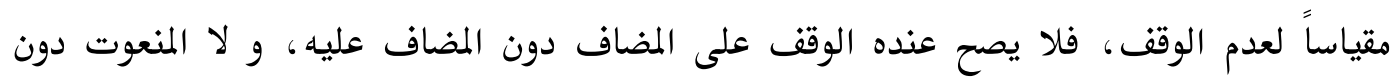

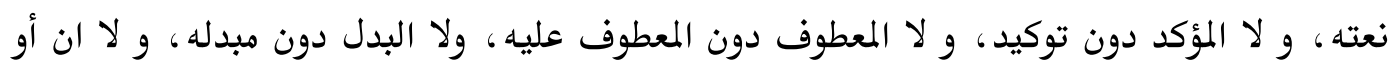

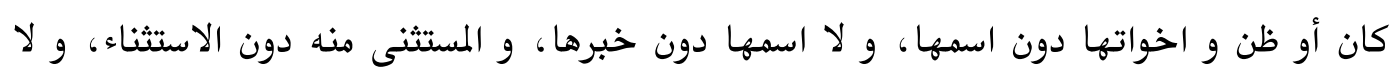
الموصول دون وصلته".

و ننظر إلى الوقف و عدمه و كيف يؤثران في الإعراب:

\begin{tabular}{|c|c|c|c|c|}
\hline سورة & إذ يجب الوقف على & \multicolumn{2}{|r|}{ الآية } & 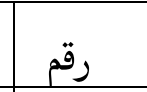 \\
\hline يوسف : ז7 & 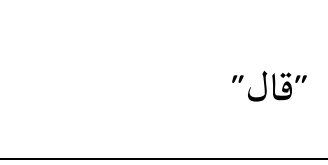 & \multicolumn{2}{|c|}{ 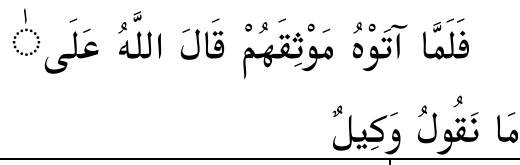 } & 1 \\
\hline \multicolumn{3}{|c|}{ 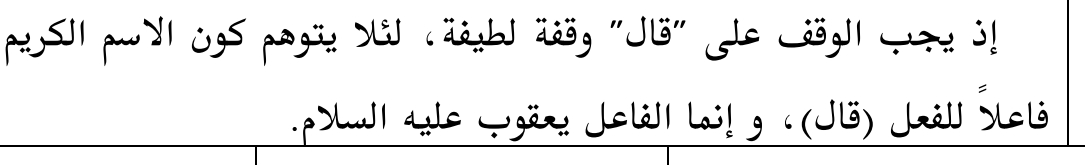 } & \multicolumn{2}{|r|}{ 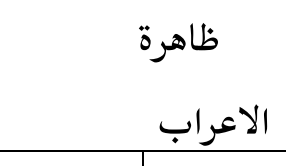 } \\
\hline 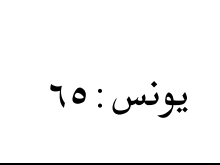 & "قَوَلهم" & \multicolumn{2}{|c|}{ 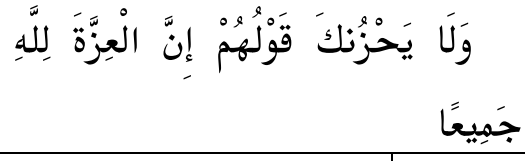 } & $r$ \\
\hline \multicolumn{3}{|c|}{ 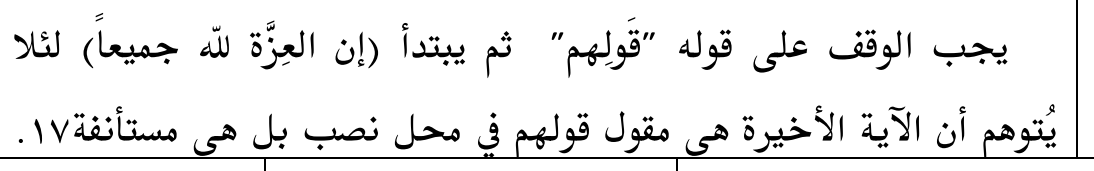 } & \multicolumn{2}{|r|}{ 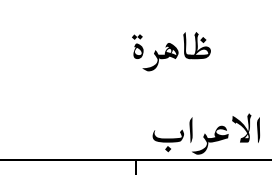 } \\
\hline الكهف:1 & "عوجا" & 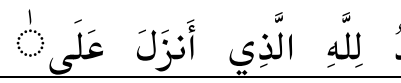 & الْحَمْدُ & $r$ \\
\hline
\end{tabular}

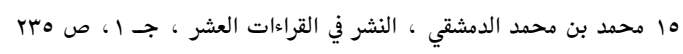

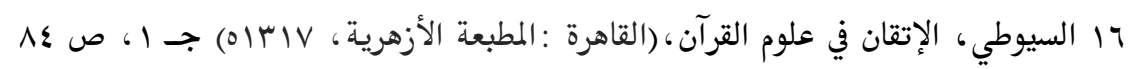

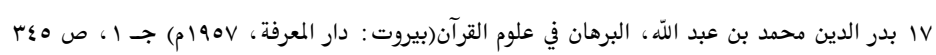

\section{'A Jamiy, Jurnal Bahasa dan Sastra Arab \\ Volume 07, No. 2, September 2018}




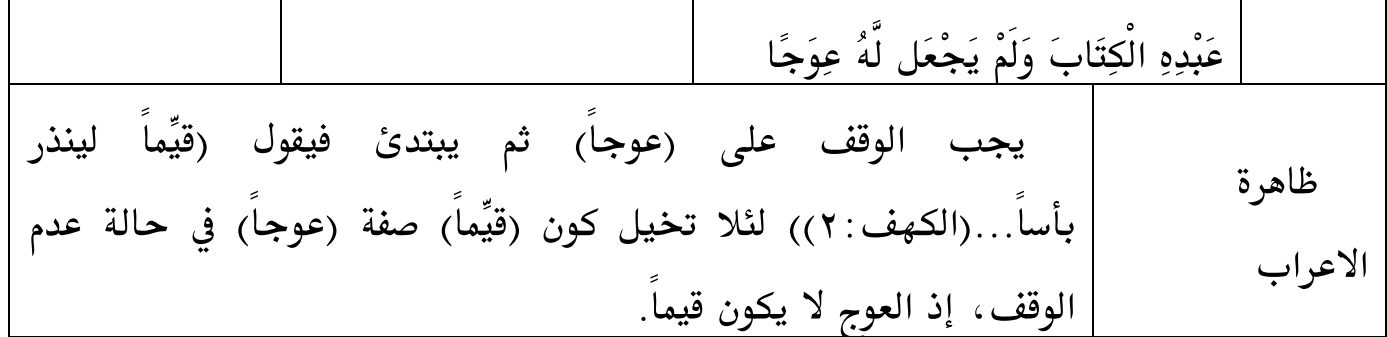

و يأتي مثالاً في وجوب الوقف عن أبيَّ بن كعب و عائشة و عروة بن الزبير و غيرهم.

\begin{tabular}{|c|c|c|c|c|}
\hline سورة & على.. إذ يجب الوقف & & الآية & قم \\
\hline v: آل عمران & " إلا الله " & 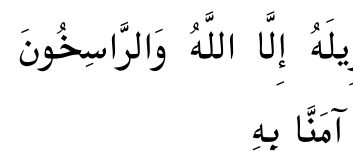 & فَيَ الْمَا يَعْلَمَ & 1 \\
\hline \multicolumn{3}{|c|}{ - - يجب الوقف على (إلاالله) على أن الراسخين في العلم لا يعلمون } & \multirow{2}{*}{\multicolumn{2}{|c|}{ ظاهرة الإعراب }} \\
\hline \multicolumn{3}{|c|}{ 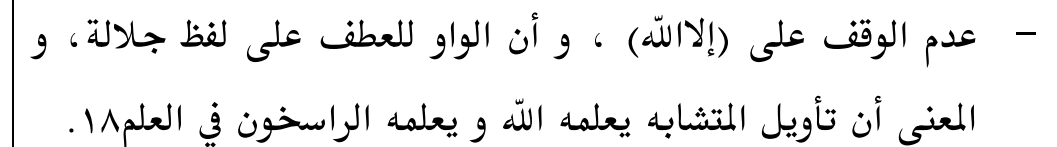 } & & \\
\hline
\end{tabular}

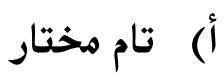

فأما الوقف تام مختار هو الذي لا يتعلق بشيء مما بعده فيحسن الوقف عليه و الابتداء بما بعده9 و من مواضعه الوقف قبل يا النداء، و فعل الأمر، و القسم ولامه دون القول و (اللّ) بعد رأس كل آية و هي كلمة آخر الآية كقافية الشعر•r و الشرط ما

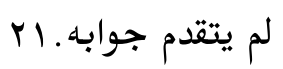

الوقف التام هو الوقف على كلام تام في ذاته ولم يتعلق بما بعده مطلقًا: لا من جهة اللفظ ولا من جهة المعنى، مثال:

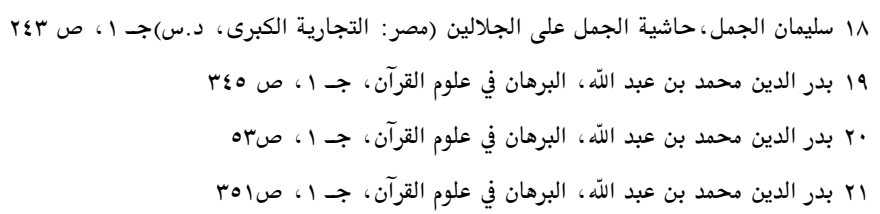

'A Jamiy, Jurnal Bahasa dan Sastra Arab Volume 07, No. 2, September 2018 


\begin{tabular}{|c|c|c|c|c|}
\hline قسم الوقف & الوقف على... & سورة & الآية & رقم \\
\hline الوقف الكافي & " وَلًَا الضَّالِّينَ & الفاتحة & 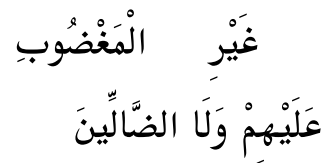 & 1 \\
\hline \multicolumn{4}{|c|}{ 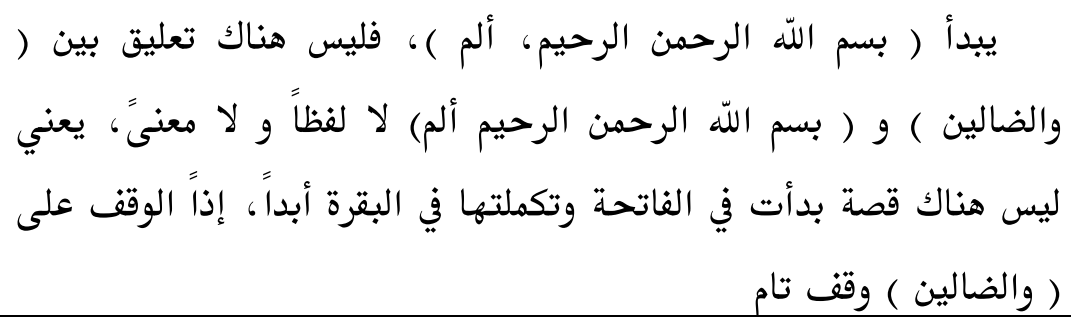 } & ظاهرة الإعراب \\
\hline
\end{tabular}

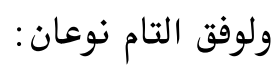

أولاً: هو الذي يلزم الوقف عليه والابتداء بما بعده؛ لأنه لو وصل بما بعده لأوهم وصله معنى" غير المعنى المراد، ومن أجل هذا يسميه بعضهم باللازمبr وبعضهم بالواجب، ويطلق على له هذا النوع التام المقيد أي المقيد باللازم أو الواجب، و يأتي مثال منه :

\begin{tabular}{|c|c|c|c|c|c|}
\hline قسم الوقف & الوقف على & سورة & \multicolumn{2}{|c|}{ الآية } & رقم \\
\hline "الازم" التام & "قولهم" & يس (T־) & \multicolumn{2}{|c|}{ 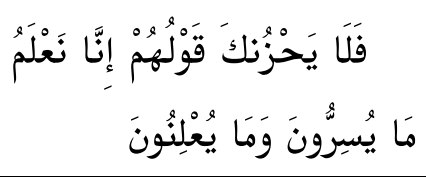 } & 1 \\
\hline \multicolumn{4}{|c|}{ كذلك. } & \multicolumn{2}{|c|}{ ظاهرة الإعراب } \\
\hline "الوقف التام & "له ولد" & $\begin{array}{l}\text { النساء: } \\
\text { |VI }\end{array}$ & \multicolumn{2}{|c|}{ 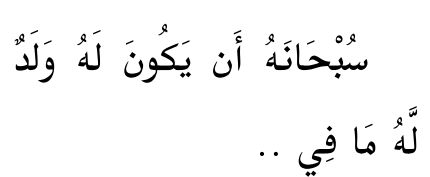 } & r \\
\hline \multicolumn{4}{|c|}{ 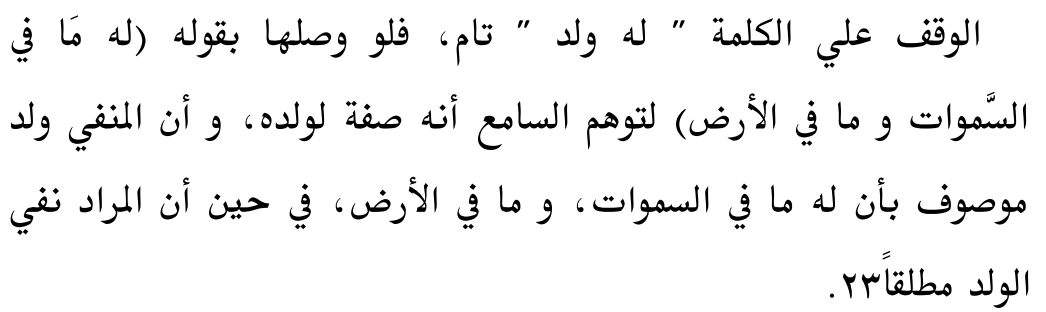 } & \multicolumn{2}{|c|}{ ظاهرة الإعراب } \\
\hline
\end{tabular}

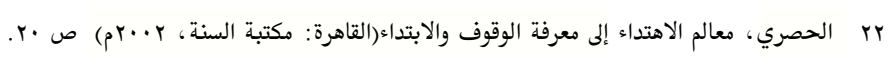

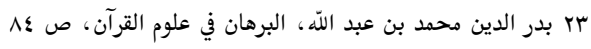

'A Jamiy, Jurnal Bahasa dan Sastra Arab Volume 07, No. 2, September 2018 


\begin{tabular}{|c|c|c|c|c|c|}
\hline الوقف التام & 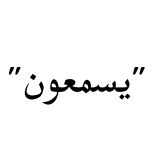 & جال & 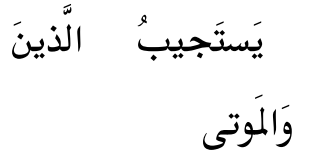 & يَسَمَعَونَ & $r$ \\
\hline \multicolumn{4}{|c|}{ 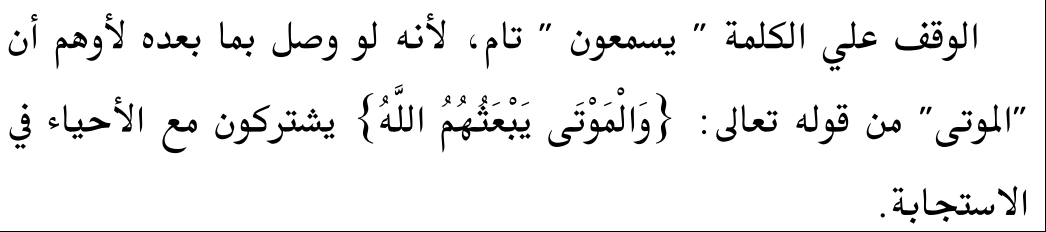 } & \multicolumn{2}{|c|}{ 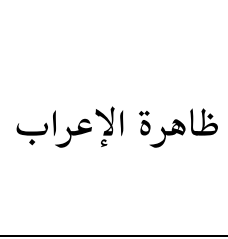 } \\
\hline \multicolumn{4}{|c|}{ يلزم الوقف عليه ويلزم الابتداء بما بعده، ومن أجل هذا سمِّى لازمًا. } & & الحك \\
\hline
\end{tabular}

ثانياً: هو الذي يحسن الوقف عليه ويحسن الابتداء بما بعده ومعنى هذا أنه يجوز وصله

بما بعده طالما أن وصله لا يغير المعنى الذي أراده الله تعالى ويسمِّيه بعضهم بالتام المطلق. وهي غالباً في أواخر السور وأواخر الآيات وانقضاء القصص ونهاية الكلام على حكم معين وقد يكون في

\begin{tabular}{|c|c|c|c|c|}
\hline قسم الوقف & الوقف على & 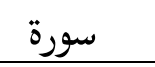 & 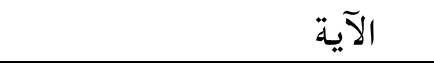 & 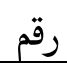 \\
\hline "مطلق" الوقف التام & 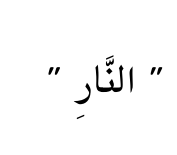 & هو البقرة: & 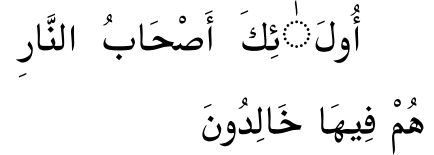 & 1 \\
\hline \multicolumn{3}{|c|}{ لأن وصله و وقفه لا يغير المعنى المراد. } & \multicolumn{2}{|c|}{ 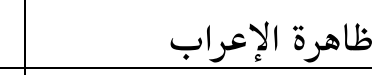 } \\
\hline \multicolumn{3}{|c|}{ يحسن الوقف عليه ويحسن الابتداء بما بعده. } & يحسن الو & الحك \\
\hline
\end{tabular}

وسمِّي الوقف التام؛ لتمام الكلام عنده وعدم احتياجه إلى ما بعده في اللفظ أو المعنى ويكون غالبًا في أواخر السور وأواخر الآيات وانقضاء القصص ونهاية الكلام على حكم معين، وقد يكون في وسط الآية وفي أواءدلها. وفيما يأتي تفصيل الكلام على كل منها:

\begin{tabular}{|c|c|c|c|c|}
\hline سورة & الابتداء & على الوقف & الآية & رقم \\
\hline 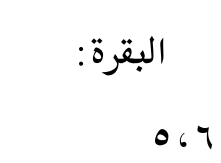 & إنَّ الَّذِينَ كَفَرَوا & نَ" الْمْفْلْحُو & وَأَوُولَبكِكَ هُمُ الْمُفْلْحُونَ & 1 \\
\hline \multicolumn{5}{|c|}{ ظاهرة الإعراب } \\
\hline
\end{tabular}

'A Jamiy, Jurnal Bahasa dan Sastra Arab Volume 07, No. 2, September 2018 


\begin{tabular}{|c|c|c|c|c|c|}
\hline 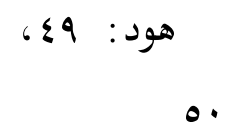 & 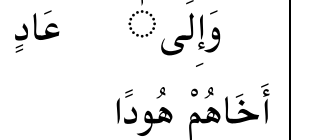 & "لِلْمَْْتَّقِينَ" & \multicolumn{2}{|c|}{ إِنَّ الْعَاقِبَةَ لِلْمَتََِِّينَ } & $r$ \\
\hline \multicolumn{4}{|c|}{ والسلام. } & \multicolumn{2}{|c|}{ ظاهرة الإعراب } \\
\hline 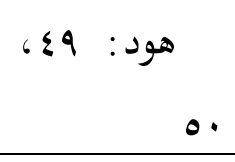 & 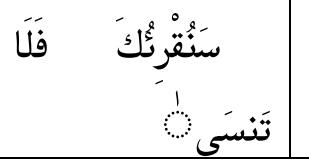 & & \multicolumn{2}{|c|}{ 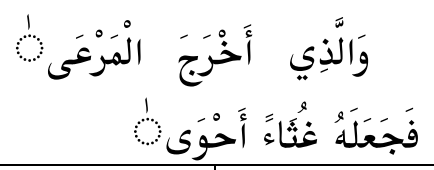 } & r \\
\hline \multicolumn{4}{|c|}{ 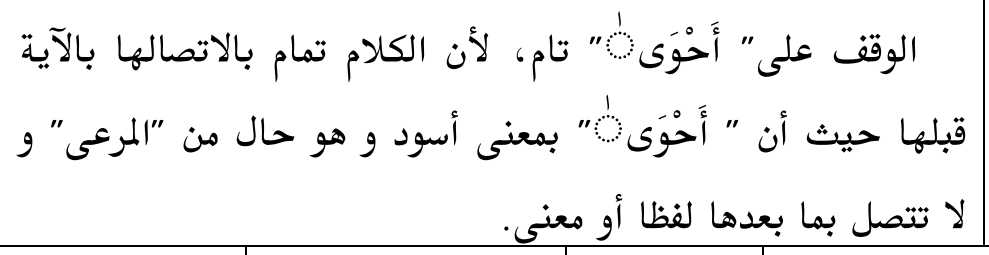 } & \multicolumn{2}{|c|}{ ظاهرة الإعراب } \\
\hline $\begin{array}{l}\text { ل لقمان } \\
|r| 1 \mid\end{array}$ & الْحَلَقَدْ آَتَينَا للُقْمَانَ & " مئين & \multicolumn{2}{|c|}{ مُبِينَ بَلِ الظَاَّلمُونَ فِي ضَلَالَ } & \\
\hline \multicolumn{4}{|c|}{ 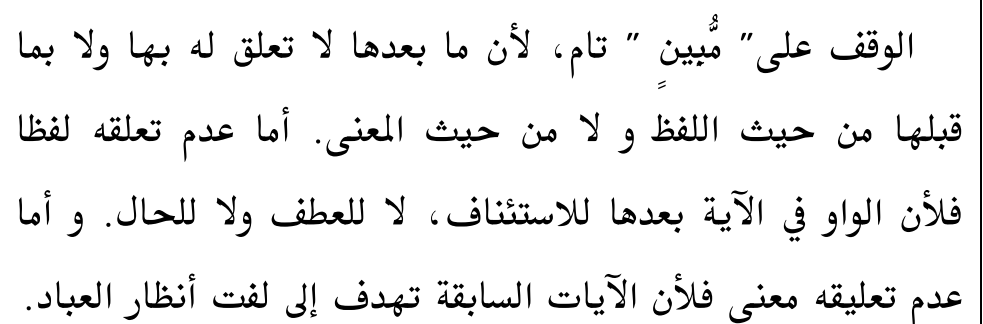 } & \\
\hline
\end{tabular}

\begin{tabular}{|c|c|c|c|c|}
\hline ته & 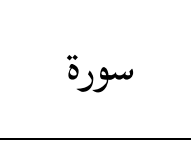 & على الوقف & 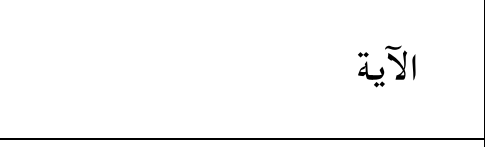 & قم \\
\hline 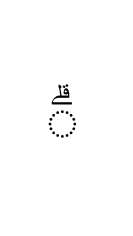 & ج الفرقان: & جَاَنَبِي "إذْ & 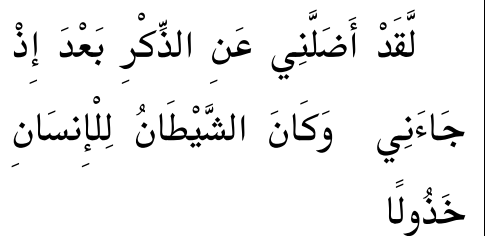 & 1 \\
\hline \multicolumn{4}{|c|}{ فهذا تمام حكاية قول الظالم وتمام الفاصلة } & لإعراب \\
\hline 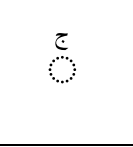 & ص: & " ذِكْرٌ " & 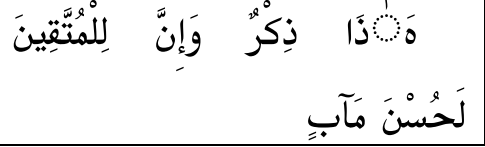 & r \\
\hline
\end{tabular}

'A Jamiy, Jurnal Bahasa dan Sastra Arab Volume 07, No. 2, September 2018 
الوقف على "ذكر" تام لأن ما بعدها لا تعلق له بها ولا بما

قبلها من حيث اللفظ و لا من حيث المعنى. فأما الواو في الكلمة

ظاهرة

التي بعدها للاستئناف، و الجملة بعدها مستأنفة مسوقة لبيان

الإعراب

مآل المتقين و الطاغين، بعد بيان أحوال المرسلين المتقدمين.

\begin{tabular}{|c|c|c|c|c|c|}
\hline ته & سورة & على الوقف & & الآية & قم \\
\hline in & لاس الصافات : اس山| & 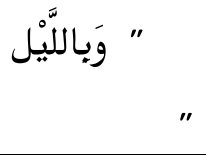 & 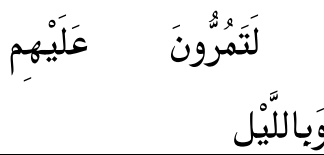 & 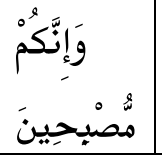 & 1 \\
\hline \multicolumn{4}{|c|}{ 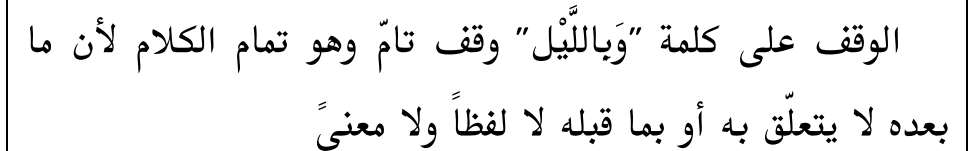 } & \multicolumn{2}{|c|}{ الإعراب } \\
\hline
\end{tabular}

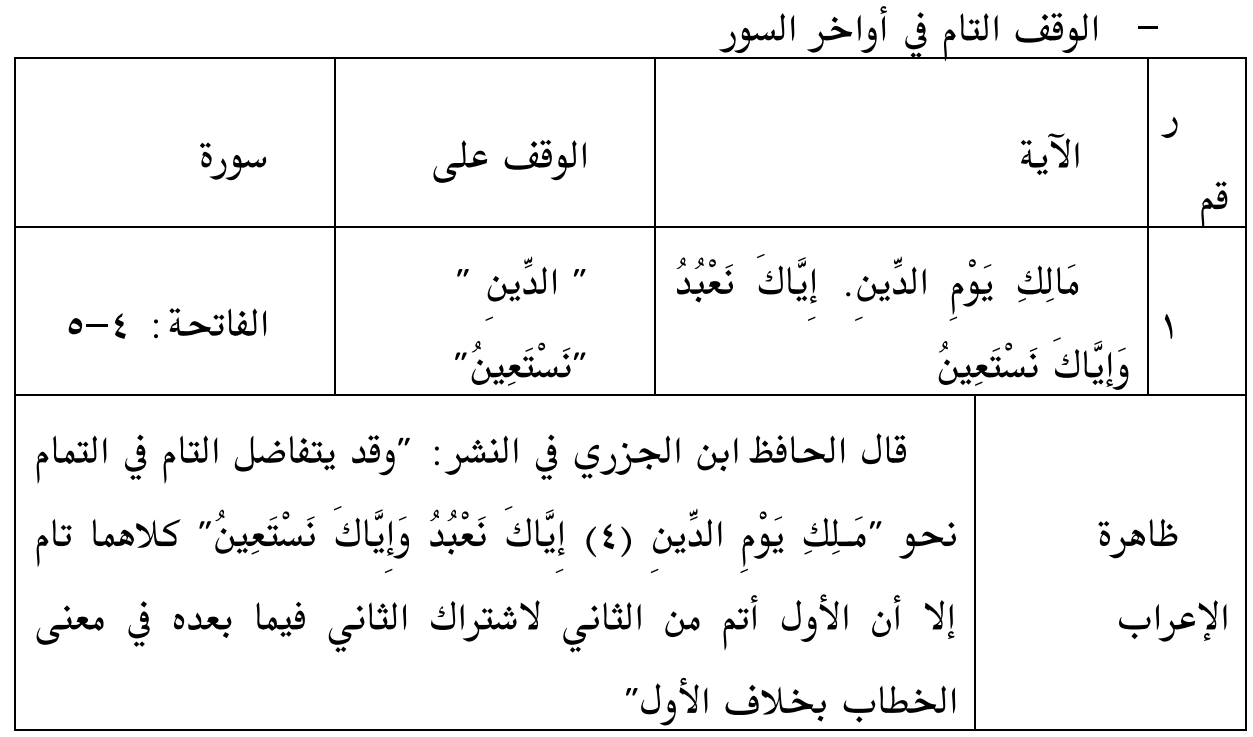

\begin{tabular}{|c|c|c|c|}
\hline \multicolumn{1}{c|}{} \\
\hline \\
\end{tabular}

'A Jamiy, Jurnal Bahasa dan Sastra Arab

Volume 07, No. 2, September 2018 


\begin{tabular}{|c|c|c|c|}
\hline البقرة: : الب • & يأتى بعده ياء النداء & 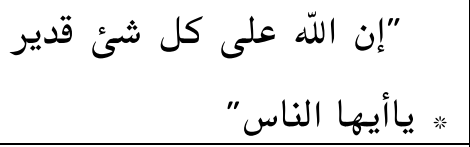 & r \\
\hline هود : ؟ § & يأتى بعده فعل أمر & 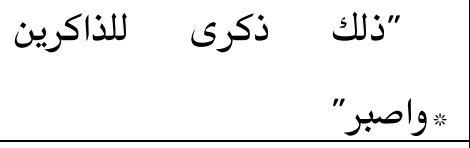 & r \\
\hline النساء: سץ| & يأتى بعده شرط & 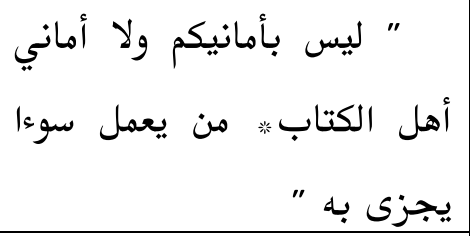 & $\xi$ \\
\hline ه البقرة: & عن اية رحمة ع اية عذاب & 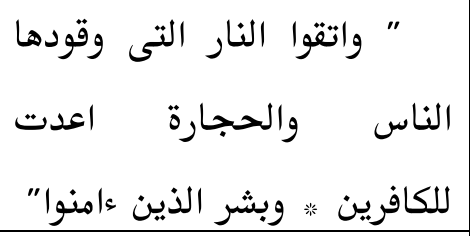 & 0 \\
\hline $\begin{array}{l}\text { الأعراف: } \\
\text { : } 109\end{array}$ & 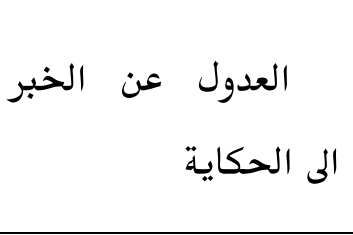 & 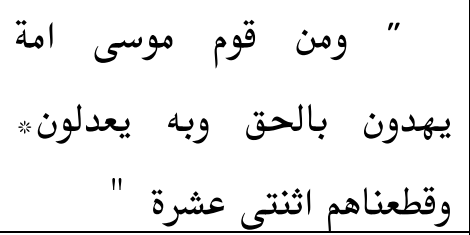 & 7 \\
\hline البقرة: • 17 & يأتى بعد الاستثناء & 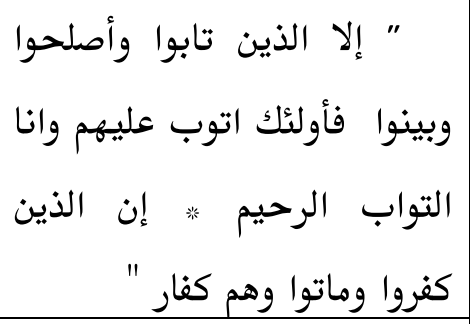 & V \\
\hline البقرة: · • & بعد انتهاء القول & 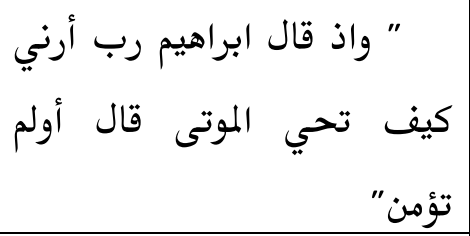 & $\Lambda$ \\
\hline $\begin{array}{l}\text { البقرة: IVY } \\
\text { IVV }\end{array}$ & 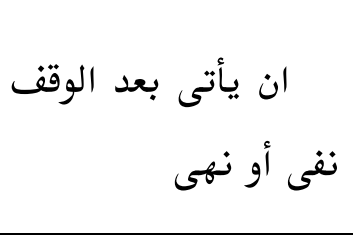 & 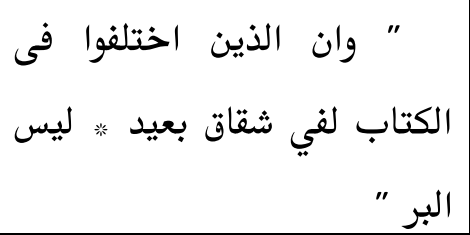 & 9 \\
\hline الجاثية: : 11 & 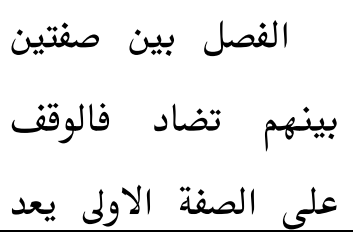 & 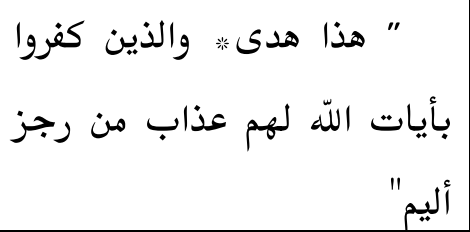 & \\
\hline
\end{tabular}

'A Jamiy, Jurnal Bahasa dan Sastra Arab Volume 07, No. 2, September 2018 


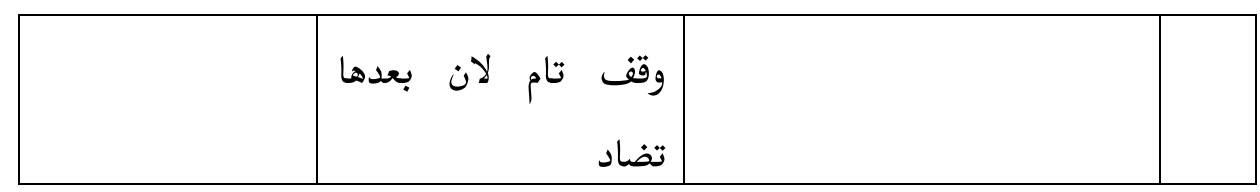

و الحكم من هذا الوقف، يحسن الوقف عليه ويحسن الابتداء بما بعده ولا يلزمنى اعاده ما قبله و علاماته فى المصحف ، اذا كان فى وسط الايه توضع علامة "قلى" معناه ان يجوز لنا الوقف والوصل والوقف أولى، ولكن اذا كان فى نهاية الاية او نهاية السورة ليس له علامة واحيانا توضع علامة " ج " على الوقف التام ومعناه جواز الوقف وجواز

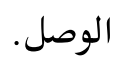
ب) كاف جائز و أما الوقف الكافي هو ما يكون منقطعاً في اللفظ متعلقاً في المعنى فيحسن الوقف

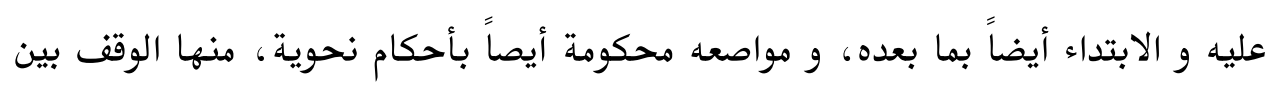

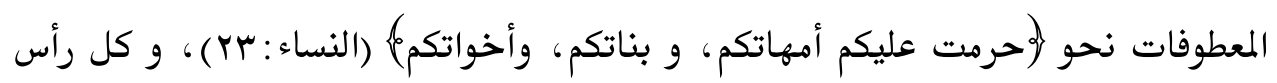
آية بعدها "لام كي"، و "إلا" بمعنى لكن، و "إن" المكسورة المشددة، و الاستفهام و "بل" لمّل و "ألا" المخففة و "السين" و "سوف" على تهدد و "نعم" و "بئس" و "كيلا" ما لم

$$
\text { يتقدمهن قول أو قسم؟r. }
$$

فنقول الوقف الكافي هو الوقف على كلمة قرآنية بينها وبين ما بعدها تعلق معنوي لا لفظي يعني ( إعرابي )، يوقف عليه ويبتدأ بما بعده، هذا هو الوقف الثاني من أنواع

\begin{tabular}{|c|c|c|c|c|}
\hline الوقف & 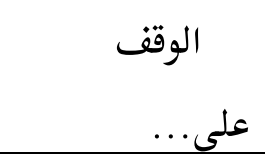 & سورة & الآية & رقم \\
\hline الوقف الوافي & " لَ يُؤْمِنْونَ & البقرة: ج & 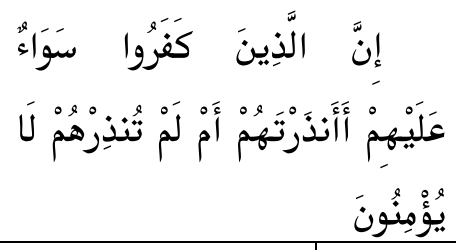 & 1 \\
\hline \multicolumn{4}{|c|}{ 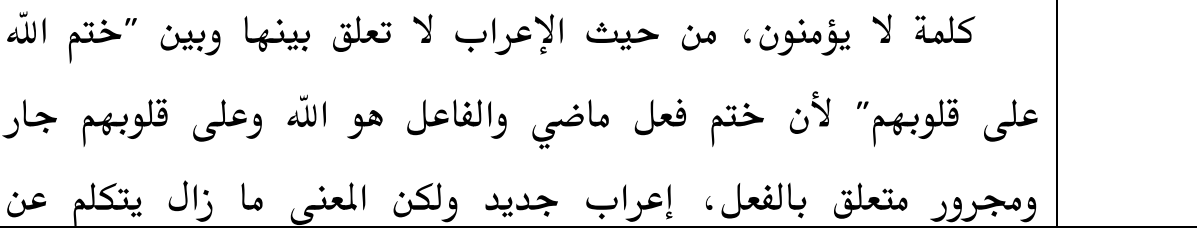 } & الإعرة \\
\hline
\end{tabular}

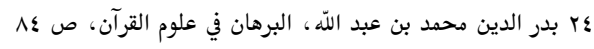

\section{'A Jamiy, Jurnal Bahasa dan Sastra Arab} Volume 07, No. 2, September 2018 


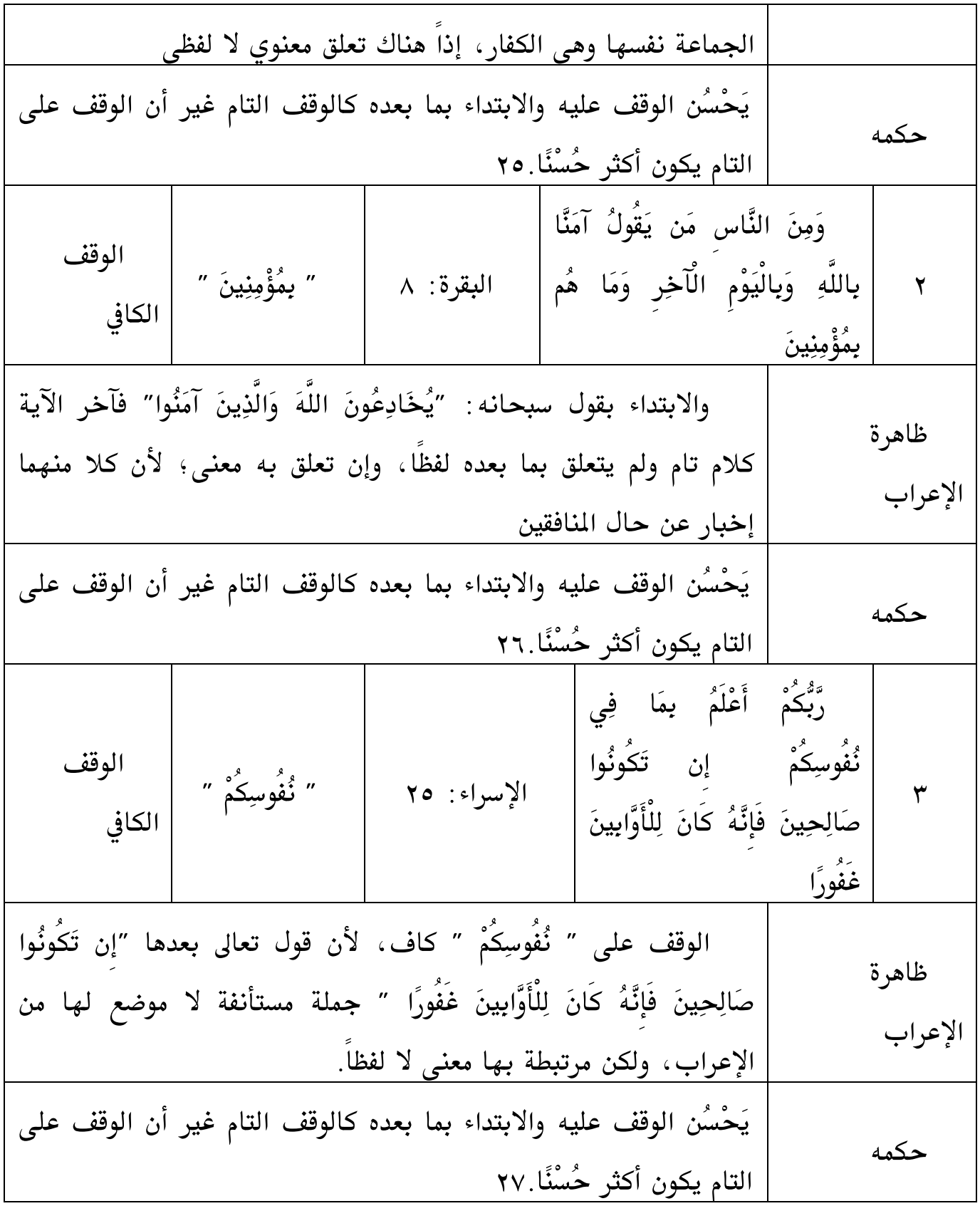

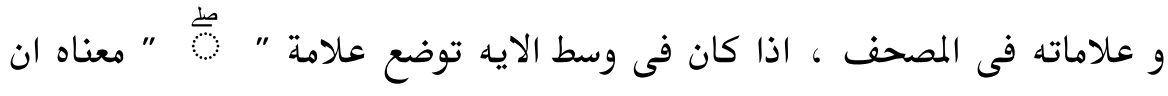
يحسن الوقف عليه والابتداء بما بعده كالوقف التام ، ولكن اذا كان فى نهاية الاية او

T ro

$$
\begin{aligned}
& \text { T Y لمحد مكي نصر، نهاية القول المفيد في علم التجويد ، ص 1T17 } \\
& \text { IT المحمد مكي نصر، نهاية القول المفيد في علم التجويد ، ص }
\end{aligned}
$$

'A Jamiy, Jurnal Bahasa dan Sastra Arab Volume 07, No. 2, September 2018 
نهاية السورة ليس له علامة و إن كان في غير رؤوس الآي فحكمه أنه يحسن الوقف عليه ولا يحسن الابتداء بما بعده لتعلقه به لفظاً ومعنى.

ت) حسن مفهوم أما تعريف لهذا النوع فقد توفر أقوال العلماء، بعضها سأذكر في القائمة التالية :

\begin{tabular}{|c|c|c|}
\hline القول & قائل & رقم \\
\hline بما بعده^r. الوقف الحسن هو الذي يحسن الوقف عليه ولا يحسنُ الابتداء & الأنباري & 1 \\
\hline الابتداء بما بعده لتعلقه بـه من جهـة الوقف الحسن الذي يحسن الوقف عليه ولا يحسن & الدانى & $r$ \\
\hline تمام الكلام عند تلك الوقف على كلمة تعلّق ما بعدها بها أو بما قبلها لفظاً بشرط & المتأخرين & $r$ \\
\hline
\end{tabular}

فأقول أن الوقف الحسن هو الذي يحسن الوقف عليه و لكن لا يحسن الابتداء بما بعده لتعلقه به من جهة اللفظ والمعنى ، و هذا ما يأتي مثال منه :

\begin{tabular}{|c|c|c|c|c|c|}
\hline قالوق & على الوقف & 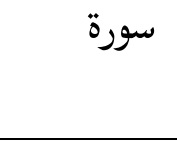 & & الآية & رقم \\
\hline الحسن الوقف & " الْحَمْدُ لِلَّهِ " & البقرة: r & لِلَّهِ رَبِّ الْعَالَمِينَ & 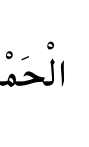 & 1 \\
\hline \multicolumn{4}{|c|}{ 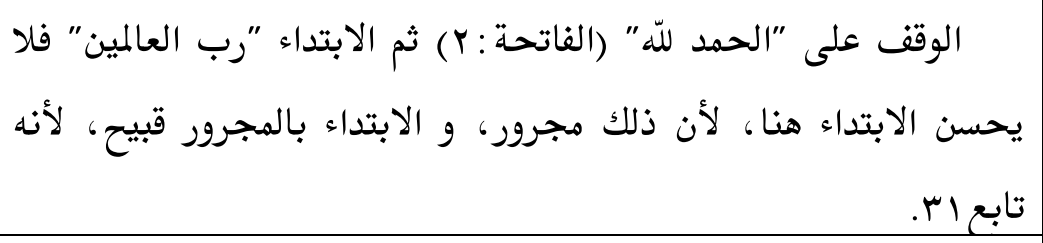 } & \multicolumn{2}{|c|}{ 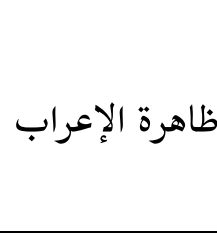 } \\
\hline \multicolumn{4}{|c|}{ يحسن الوقف عليه و لكن لا يحسن الابتداء بما بعده } & \multicolumn{2}{|c|}{ حكمه } \\
\hline
\end{tabular}

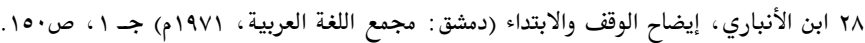
هץ أبي عمرو الداني ، المكتفى في الوقف و الابتداء (بيروت : جميع حقوق المحفوظة ، 9AV (م) ص هـأ. r. المحمد مكي نصر،نهاية القول المفيد في علم التجويد، ص 191.

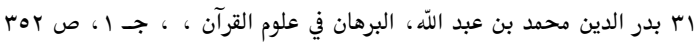

'A Jamiy, Jurnal Bahasa dan Sastra Arab Volume 07, No. 2, September 2018 


\begin{tabular}{|c|c|c|c|c|c|}
\hline الحسن الوقف & " وَبَرْقُ " & البقرة: 19 & 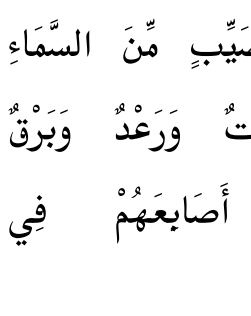 & 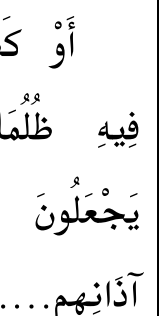 & $r$ \\
\hline \multicolumn{4}{|c|}{ 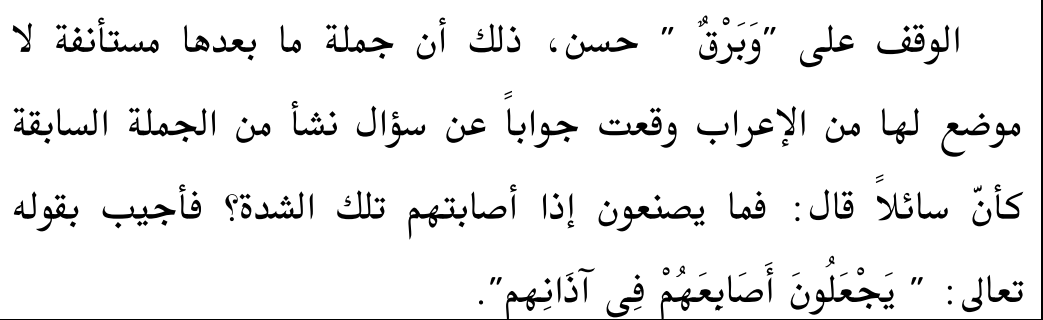 } & الإعراب & \\
\hline
\end{tabular}

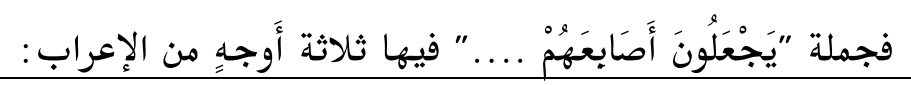

\begin{tabular}{|c|c|}
\hline أوجه من ظاهرة الإعراب & 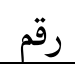 \\
\hline 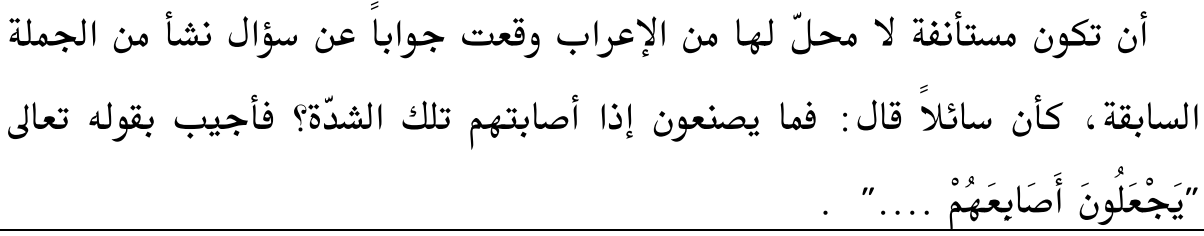 & 1 \\
\hline كأنه قيل "جاعلين". لها موضعاً من الإعراب وهو الجرّ لأنها في موضع الصفة لـ "ذوي" المحذوف & r \\
\hline والراجع على ذي الحال محذوف في موضع نصب على الحال من الضمير الذي هو الهاء في "فِيَهِ"، & $r$ \\
\hline
\end{tabular}

من الأوجه السابقة أرى الكاتب أن الراجح عند أكثر المحققين من المفسرين في

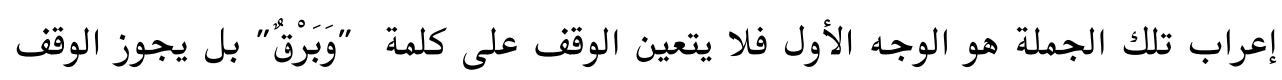

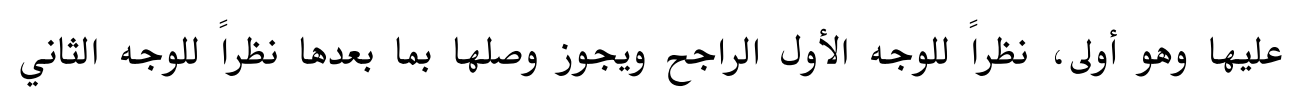

\begin{tabular}{|c|c|c|c|c|}
\hline قسم الوقف & الوقف على... & سورة & الآية & رقم \\
\hline الحقف & " وَعَصَيْنَا " & البقرة: هو & 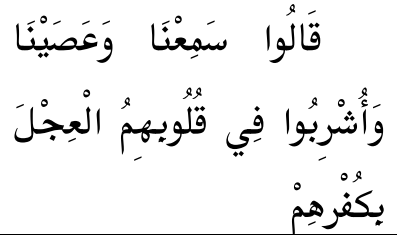 & $r$ \\
\hline
\end{tabular}

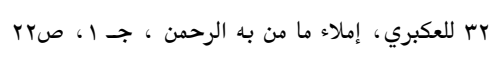

'A Jamiy, Jurnal Bahasa dan Sastra Arab Volume 07, No. 2, September 2018 
الوقف الصالح هو الوقف على كلمة "وَعَصَيْنَا" فجملة "وَأُشْرُبوا....فيها وجهان من

\begin{tabular}{|c|c|c|}
\hline & رقم \\
\hline \multicolumn{2}{|c|}{ أن تكون لها محل من الإعراب فيحتمل: } & \multirow[t]{2}{*}{1} \\
\hline أن تكون معطوفة على جملة "قَالَّاْ ". & 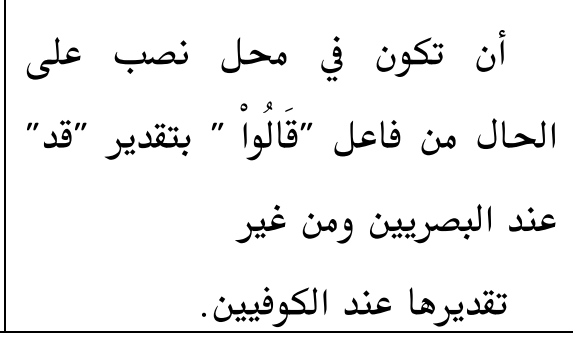 & \\
\hline \multicolumn{2}{|c|}{ 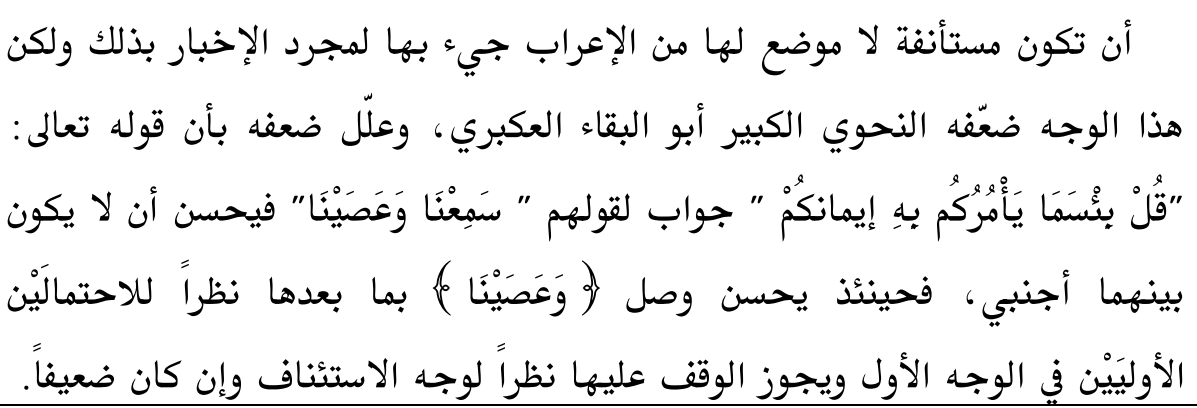 } & $r$ \\
\hline
\end{tabular}

فالوجه المشترك بين الوقف الحسن والصالح عندهما هو أنّ الكلام قبلها أفاد فائدة يحسن السكوت عليه، وما بعدها جملة متعلقة بما قبلها في المعنى وأما في اللفظ ففي (الحسن) لا تعلق على الراجح وأمّا في (الصالح) فالتعلّق اللفظي راجح.

$$
\text { ث) قبيح متروك }
$$

تعريف لهذا النوع فقد توفر أقوال العلماء، بعضها سأذكر في القائمة التالية:

\begin{tabular}{|c|c|c|}
\hline القول & قائل & رقم \\
\hline هو أن يتصل ما بعده بما قبله لفظاً ومعنىَّب & 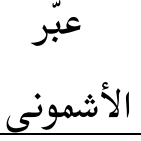 & 1 \\
\hline أنَّ الوقف القبيح هو الذي لا يعرف المراد منه عس. & أبو الدانى & $r$ \\
\hline
\end{tabular}

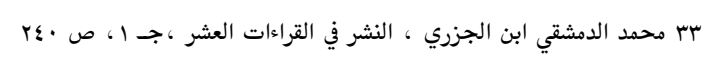

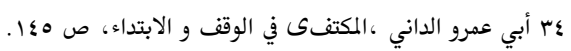

\section{'A Jamiy, Jurnal Bahasa dan Sastra Arab}




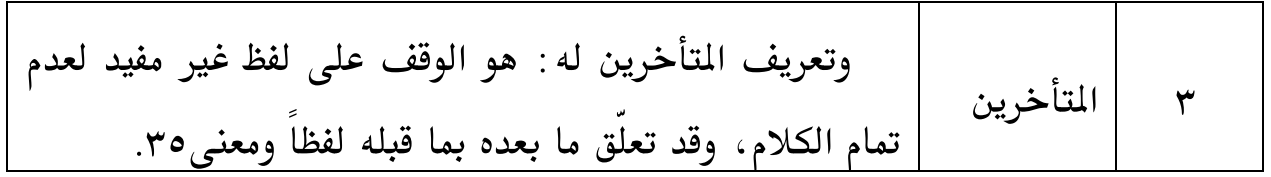

الوقف القبيح هو الآخر مقِيس بمقاييس الذحو فلا يوقف على الموصوف دون

الصفة، و الزمخشري يحوز ذلك إذا كانت الصفة مقطوعة نحو "و من شر الوسواس

الخناس" (الناس: ؟) هنا الوقف ثم يبتدئ "الذي يوسوس" (الناس:0) إن جعله القارئ

على القطع بالرفع أو بالنصب؟س.

r إهرة الإعراب في الابتداء

إنّ الابتداء في اصطلاح علماء القراءات هو الشروع في قراءة كتاب اللّ سواء كان بعد قطع

وانصراف عنها أو بعد وقف، فإذا كان بعد قطع فلا بد فيه من مراعاة أحكام الاستعاذة والبسملة،

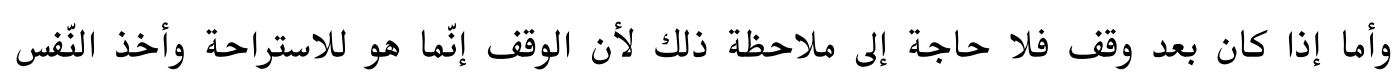

فقطVr.

فلا يكون الابتداء في التلاوة إلاًّ اختيارياً لأنّهَ ليس كالوقف تدعو إليه ضرورة، فلا يجوز إلاّ بمستقلّ بالمعنى موفٍ بالمقصودیr، فإن أخل بالمعنى المقصود أو أوهم خلاف المراد كان قبيحاً

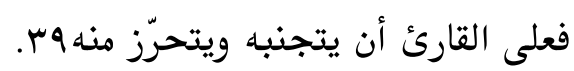

فعلى هذا أقسم الابتداء إلى قسمين : حسن و قبيح.

( ) الابتداء الحسن

هو الابتداء بكلام مستقل في المعنى بحيث لا يغير ما أراده الله تعالى، ويكون ذلك بعد وقف

تام أو كافٍ وأمثلته واضحة جليّة لا تحتاج إلى بيان.

r) ( الابتداء القبيح

هو الابتداء بكلام ناقص مخلّ بالمعنى المقصود أو موهم خلاف المراد، فالقبح فيه

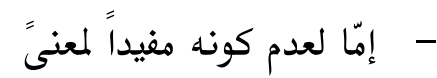

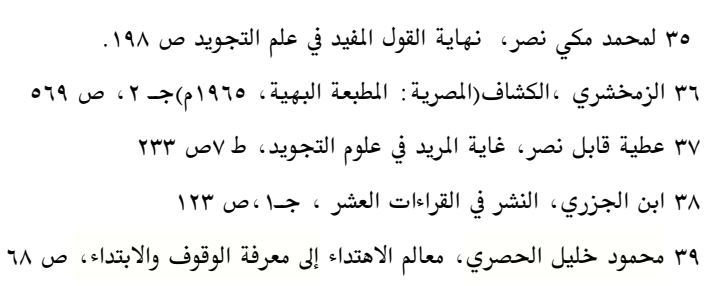

'A Jamiy, Jurnal Bahasa dan Sastra Arab

Volume 07, No. 2, September 2018 


\begin{tabular}{|c|c|c|c|}
\hline سورة & 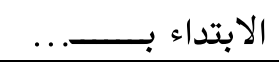 & الآية & 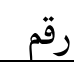 \\
\hline المسد : 1 & "أَبِي لَهَبِ وَتَبَّ" & تَبَّتْ يَدَا أَبِي لَهَبِ وَتَبَّ & 1 \\
\hline
\end{tabular}

فأقول أن الابتداء بالمفعول به أو المضاف إليه أو الحال أو التمييز أو المعطوف أو البدل وما

شابه ذلك هو الابتداء بلفظ من متعلقات جملة قبلها.

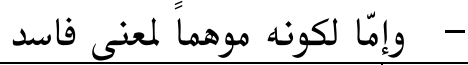

\begin{tabular}{|c|c|c|c|}
\hline سورة & 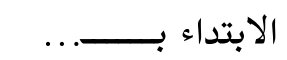 & الآية & 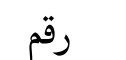 \\
\hline فاطر :r & " غَيَرْ اللَّهِ يَرْزْقُكُم" & 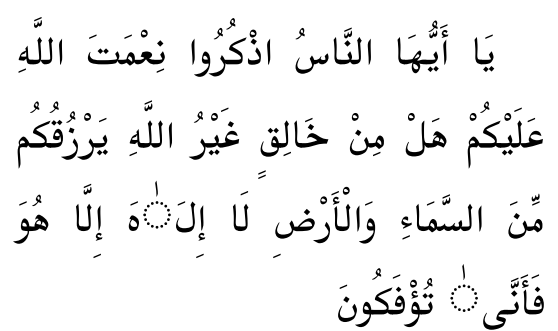 & 1 \\
\hline \multicolumn{3}{|c|}{ 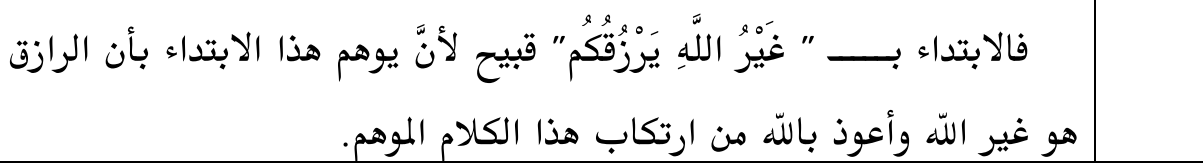 } & إمراب \\
\hline
\end{tabular}

\begin{tabular}{|c|c|c|c|}
\hline سورة & الابتداء بــــــ... & الآية & 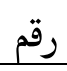 \\
\hline التوبة : · · & " الْمَسِيحُ ابْنْ اللَّهِ " & 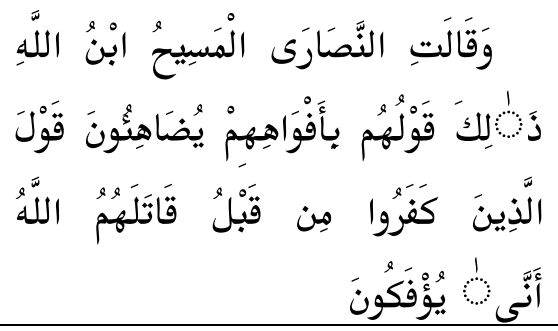 & 1 \\
\hline التوبة : ·ץ & "عُزَيْرِ ابْنْ اللَّهِ " & 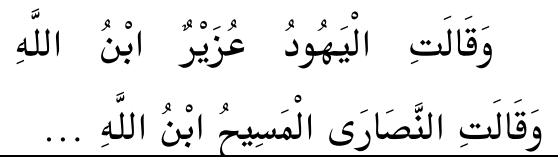 & r \\
\hline عمران : & " إِنَّ اللّهَ فَقِيرِ " & 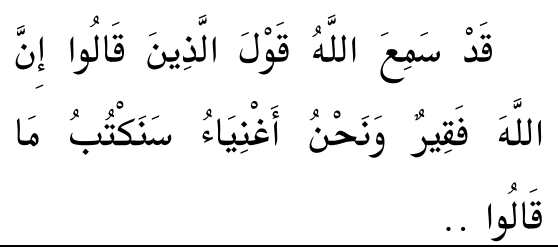 & r \\
\hline المائدة: س & 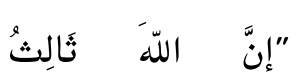 & للَّدَْْ كَفَ الَّذِينَ قَالَوا إنَّ اللَّهَ ثَالِلثُ & $\varepsilon$ \\
\hline
\end{tabular}

'A Jamiy, Jurnal Bahasa dan Sastra Arab 


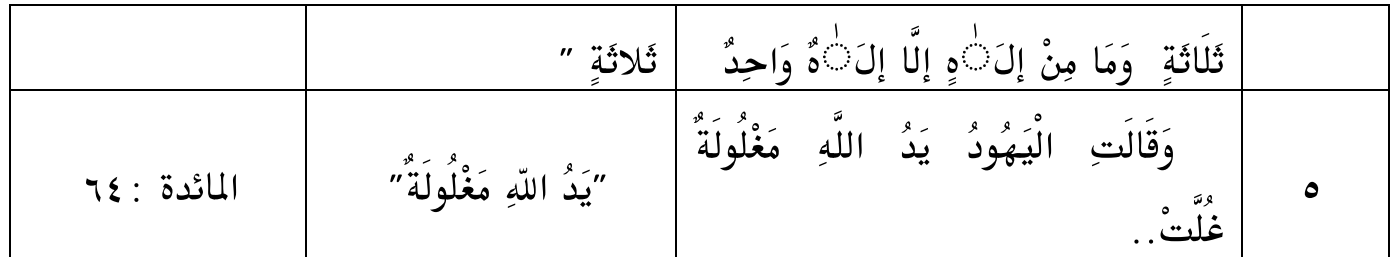

\section{ج. الخلاصة ا ـ مظاهر الإعراب في الوقف تتكون من:

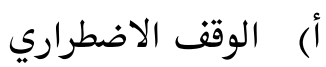

ب) الأخير الوقف الاختياري بالياء المثناة التحتية وله أربعة أنواع وهي:الوقف التام، الوقف الكافي، الوقف الحسن، الوقف القبيح.

r. - مظاهر الإعراب في الابتداء تتكون من:

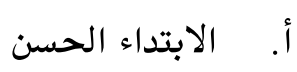
ب. ب. الابتداء القبيح r. ظاهرة الإعراب يؤثر كثيراً في تفسير أهل الرأي للقرآن و هم كالمعتزلة و المتصفون و الشيعة. هم اتخذوا من الإعراب وسيلة لتأييد مذهبم العقدي بوسائل التأويل المختلفة.

$$
\text { المراجع }
$$

$$
\text { القرآن الكريم }
$$

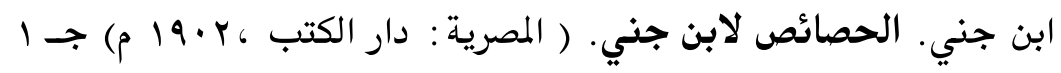

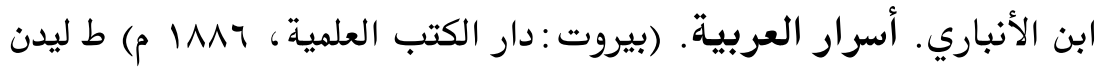

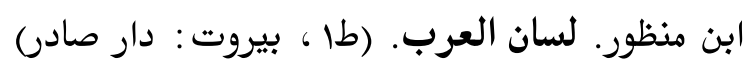

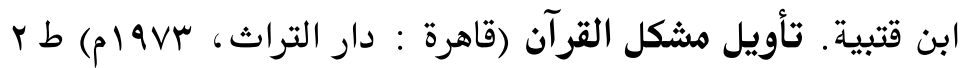

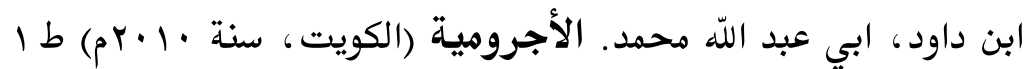

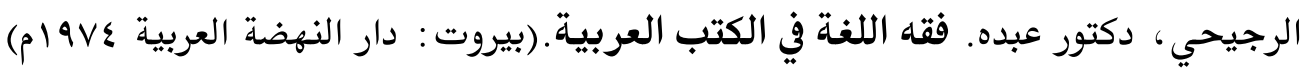

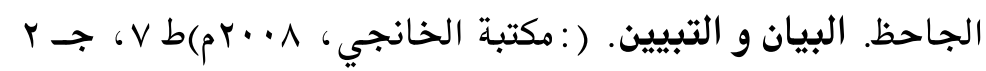

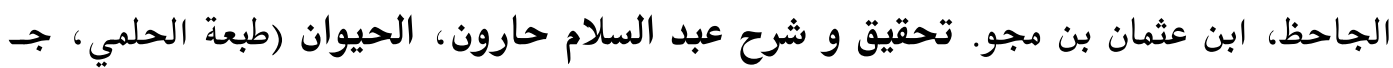

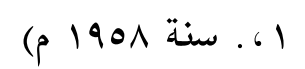

الأنصري، ابن هاشم. شرح شذور الذهب.( التحارية الكبرى) الهمان

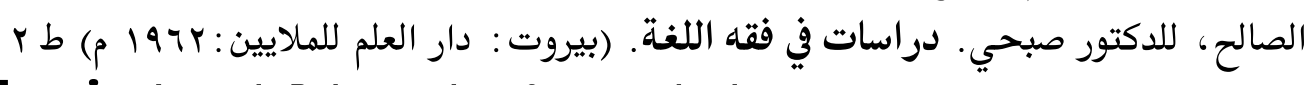

'A Jamiy, Jurnal Bahasa dan Sastra Arab 
$r \cdot r$

الفيروز آبادي، محمد ابن يعقوب. القاموس المحيط (بيروت : دار الفكر، و9901م)

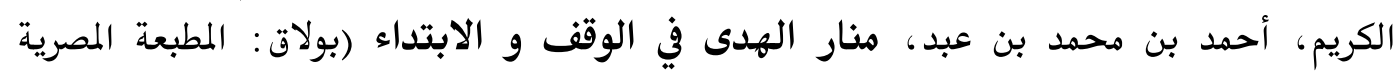

(0) YAT

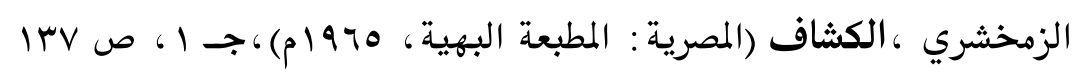

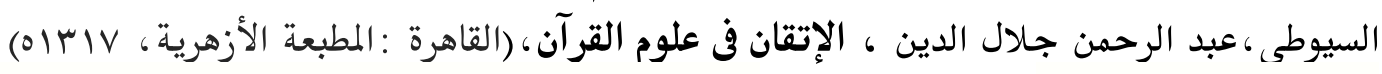

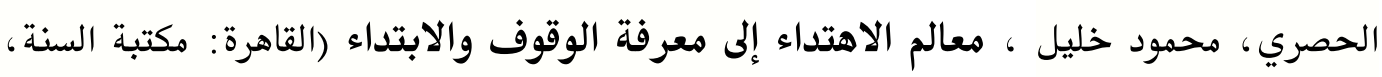
( $r$ r...r

الداني، الإمام المقرئ أبي عمرو ، المكتفى في الوقف و الابتداء (بيروت :جميع حقوق المحفوظة، (p) $9 \wedge \mathrm{V}$ 